\title{
The Phytoalexin-Inducible Multidrug Efflux Pump AcrAB Contributes to Virulence in the Fire Blight Pathogen, Erwinia amylovora
}

\author{
Antje Burse, Helge Weingart, and Matthias S. Ullrich \\ School of Engineering and Sciences, International University Bremen, Campusring 1, 28759 Bremen, Germany \\ Submitted 8 August 2003. Accepted 17 September 2003.
}

\begin{abstract}
The enterobacterium Erwinia amylovora causes fire blight on members of the family Rosaceae, with economic importance on apple and pear. During pathogenesis, the bacterium is exposed to a variety of plant-borne antimicrobial compounds. In plants of Rosaceae, many constitutively synthesized isoflavonoids affecting microorganisms were identified. Bacterial multidrug efflux transporters which mediate resistance toward structurally unrelated compounds might confer tolerance to these phytoalexins. To prove this hypothesis, we cloned the $\operatorname{acr} A B$ locus from $E$. amylovora encoding a resistance nodulation division-type transport system. In Escherichia coli, AcrAB of E. amylovora conferred resistance to hydrophobic and amphiphilic toxins. An acrB-deficient $E$. amylovora mutant was impaired in virulence on apple rootstock MM 106. Furthermore, it was susceptible toward extracts of leaves of MM 106 as well as to the apple phytoalexins phloretin, naringenin, quercetin, and (+)-catechin. The expression of $a c r A B$ was determined using the promoterless reporter gene $e g f p$. The $a c r A B$ operon was up-regulated in vitro by the addition of phloretin and naringenin. The promoter activity of $a c r R$, encoding a regulatory protein involved in $\operatorname{acr} A B$ expression, was increased by naringenin. In planta, an induction of $a c r A B$ was proved by confocal laser scanning microscopy. Our results strongly suggest that the AcrAB transport system plays an important role as a protein complex required for virulence of $E$. amylovora in resistance toward apple phytoalexins and that it is required for successful colonization of a host plant.
\end{abstract}

Additional keywords: E. coli KAM3; hypersensitive response; minimal inhibitory concentration; RND superfamily; TetR family.

Flavonoids, isoprenoids, and alkaloids compose three major classes of secondary metabolites synthesized by higher plants. These compounds are an essential part of adaptation to the life of plants as sedentary organisms. They are implicated in a broad range of physiological processes and have been considered to be important players in the protection of plants against potential pathogens. They may be preformed compounds present in healthy plant tissue or may be synthesized de novo in

Corresponding author: M. S. Ullrich; Telephone: +49-421-200 3245; Fax: +49-421-200 3249; E-mail: m.ullrich@iu-bremen.de

Nucleotide sequence data reported are available in the GenBank database under accession number AY307102. response to pathogen attack (Osbourn 1996). Successful pathogens must be able to circumvent the toxic effect of these plant inhibitors (VanEtten et al. 2001). Resistance strategies to combat antibiotics include enzymatic inactivation, alteration of the target structure, and reduced uptake (Walsh 2000). A further mechanism involves membrane-bound efflux pumps capable of transporting cytotoxic compounds. In contrast to specific resistance mechanisms, a large number of so-called multidrug efflux transporters has been found to recognize and efficiently expel a broad range of structurally unrelated compounds from the cell (Blackmore et al. 2001; van Bambeke et al. 2000). These proteins either mediate high-level resistance or confer low-level protection that facilitates the initial survival of the organism and, thus, provides it with the opportunity to acquire one of the specific high-level resistance mechanism mentioned above.

So far, much emphasis has been put on investigation of multidrug resistance phenomena in human pathogens. Hence, analysis of genomes of various other microorganisms revealed the ubiquitous occurrence of multidrug efflux pumps (Paulsen et al. 2001). In plant pathogens, the protection against toxic compounds by these transporters has been studied particularly in fungal organisms. Recent research revealed that ATP-binding cassette $(\mathrm{ABC})$ transporters, which are powered by hydrolysis of ATP, mainly contribute to virulence of phytopathogenic fungi by reducing the toxic effect of phytoalexins (Del Sorbo et al. 2000). Mutation of multidrug resistance-mediating ABC transporters of Gibberella pulicaris and Botrytis cinerea resulted in decreased tolerance to phytoalexins and, thus, led to impaired virulence (Fleißner et al. 2002; Schoonbeek et al. 2001).

In bacteria, multidrug efflux is mediated mostly by secondary transporters which utilize transmembrane electrochemical gradients, typically the proton motive force, for this process. Four cytoplasmic membrane transport protein families have been described that include multidrug efflux systems of bacteria: the major facilitator superfamily (MFS) (Pao et al. 1998; Saier et al. 1999), the resistance-nodulation-cell division (RND) superfamily (Tseng et al. 1999), the small multidrug resistance (SMR) family (Paulsen et al. 1996), and the multidrug and toxic compound extrusion (MATE) family (Brown et al. 1999). In phytopathogenic and plant-associated bacteria, only a small number of multidrug efflux pumps, classified into the MFS and RND superfamily, has been identified; for example, in Agrobacterium tumefaciens (Palumbo et al. 1998; Peng and Nester 2001), in the nitrogen-fixing root-nodule symbiont Rhizobium etli (Gonzáles-Passayo and Martínez-Romero 2000), and in Bradyrhizobium japonicum (Krummenacher and Narberhaus 2000). However, very little has been reported about their contribution to pathogenesis. 
One of the economically important bacterioses represents fire blight on rosaceous plants, which is especially destructive to apple and pear trees (Eastgate 2000). The causal agent of this disease is Erwinia amylovora (Burrill) Winslow et al., a member of the family Enterobacteriaceae. The initial symptom of fire blight is water soaking, followed by wilting and rapid necrosis, leaving infected tissue with a scorched, blackened appearance. The spread of the pathogen through the host tissue into all parts of a plant can lead to the loss of entire trees (Vanneste and EdenGreen 2000). The commercial implications of fire blight outbreaks are aggravated by the limited effectiveness of current control strategies (Psallidas and Tsiantos 2000). Understanding of the interactions between plant and pathogen can lead to improved design of antibacterial compounds and genetically engineered plants.

In E. amylovora, two factors essential for pathogenesis have been identified: the extracellular polysaccharide amylovoran (Bellemann and Geider 1992) and the hrp/dsp genes encoding a type III protein secretion system and disease-specific effector proteins, respectively (Barny et al. 1990; Steinberger and Beer 1988; Vanneste et al. 1990). Recent studies revealed a number of factors that are not directly involved in the induction of disease symptoms, but allow the pathogen to survive in planta (Aldridge et al. 1997; Bogs and Geider 2000; Expert et al. 2000; Metzger et al. 1994).

Resistance mechanisms to bypass the antimicrobial effect of secondary metabolites of the host defense have not been studied in E. amylovora before. Our present study focuses on the involvement of a general resistance mechanism, the multidrug efflux, in the virulence of E. amylovora. We examined the role of the RND-type efflux system, Acriflavine resistance (AcrAB), in this plant pathogen. In Escherichia coli, AcrAB has been recognized as one of the major multidrug efflux systems which confers resistance to a broad range of noxious dyes, detergents, and antibiotics (Nishino and Yamaguchi 2001; Okusu et al. 1996; Sulavik et al. 2001). The structural analysis of AcrB of Escherichia coli by Murakami and associates (2002), representing the first high-resolution structure of a multidrug resistance pump, improved the understanding of mechanisms underlying multidrug transport. Herein, we report on the isolation of genes encoding AcrAB in E. amylovora, which shows significant homology to the cognate major multidrug transporter of Escherichia coli. Mutation of acrB in E. amylovora dramatically reduced tolerance to apple phytoalexins as well as virulence on apple plants. Furthermore, in vitro promoter activity of $a c r A B$ as well as $a c r R$ was analyzed by transcriptional fu-

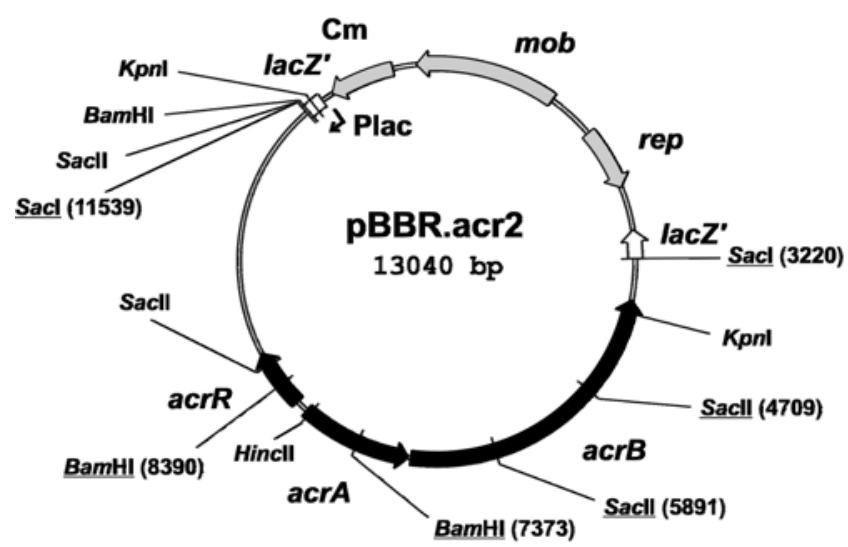

Fig. 1. Restriction map of plasmid pBBR.acr2 carrying the acrRABregion of Erwinia amylovora. Restriction sites used for subcloning were underlined. $\mathrm{Cm}$, chloramphenicol acetyltransferase; mob, gene required for plasmid mobilization; rep, gene required for plasmid replication; lac $Z^{\prime}$, encode for the first 146 amino acids of $\beta$-galactosidase. sions of these genes with the reporter gene egfp. The respective in planta promoter activities were analyzed by confocal laser scanning microscopy.

\section{RESULTS}

Identification of an acrB-homologue in E. amylovora.

To study the influence of multidrug efflux on disease development of fire blight on rosaceous plants caused by E. amylovora, a DNA region containing the acrAB genes was subcloned. According to the published nucleotide sequence encoding AcrB from Escherichia coli, oligonucleotide primers acrB_Ec_fwd and acrB_Ec_rev were designed to amplify an approximately $1.8-\mathrm{kb}$ polymerase chain reaction (PCR) product from genomic DNA of Escherichia coli strain TG1, which was used as a DNA probe in subsequent Southern blot analysis. Hybridization was performed under conditions of low stringency at $50^{\circ} \mathrm{C}$ with genomic DNA from E. amylovora strain Ea1189 digested with BamHI, ClaI, HindIII, and SacI, respectively. Hybridization signals indicated the presence of $a c r B$-homologues in the genome of E. amylovora (data not shown). Restriction enzymes ClaI and SacI providing hybridizing fragments of $>6 \mathrm{~kb}$ were used to digest genomic DNA for shotgun cloning of the acrB-homologous region from E. amylovora.

\section{Cloning of acrRAB from $E$. amylovora} and nucleotide sequence analysis.

Plasmid pBBR.acr2 was obtained by restriction digest of Ea1189 genomic DNA, ligation into pBBR1MCS, and transformation into Escherichia coli KAM3 $(a c r A B)$ with selection on crystal violet containing agar plates. Mutant KAM3 cannot export crystal violet due to lack of the respective transport system (Nishino and Yamaguchi 2001). Therefore, this mutant is highly susceptible toward crystal violet and can be used for a direct selection of the $a c r A B$ locus. The sequence of the $8.5-\mathrm{kb}$ $\mathrm{SacI}$ insert was determined and revealed the presence of three complete open reading frames (ORFs) (Fig. 1). Based on significant sequence similarities with other RND-type efflux systems, the three genes were designated $\operatorname{acr} A, \operatorname{acr} B$, and $a c r R$.

The $a c r B$ gene of $E$. amylovora codes for a protein of 1,048 amino acids, with a predicted molecular mass of $112.9 \mathrm{kDa}$. Topology analysis of the deduced AcrB sequence with the computer program HMMTOP2.0 revealed a typical pattern of RND-type membrane proteins (i.e., 12 hydrophobic domains, presumably corresponding to transmembrane segments [TMS] and two large $[\approx 300$ residues] hydrophilic periplasmic loops located between TMS 1 and 2 and TMS 7 and 8, respectively). The deduced AcrB sequence was compared with protein database entries by using the BLASTP program (Altschul et al. 1997). It shows similarity to members of multidrug efflux transporters assigned to the RND superfamily (Tseng et al. 1999), including AcrB of Enterobacter aerogenes with $80 \%$ identity (Pradel and Pagès 2002), AcrB of Escherichia coli with 79\% identity (Ma et al. 1993), MexB of Pseudomonas aeruginosa with 66\% identity (Poole et al. 1993), TtgB of $P$. putida with $64 \%$ identity (Ramos et al. 1998), and IfeB of $A$. tumefaciens with 50\% identity (Palumbo et al. 1998).

The acrA gene product, located upstream of $a c r B$, is predicted to contain 397 amino acids with a molecular mass of $42.3 \mathrm{kDa}$. AcrA possesses a 24-bp N-terminal signal sequence, including a consensus lipoprotein-processing site (LTAC). The AcrA sequence exhibits similarity to various members of the membrane fusion protein (MFP) superfamily (Dinh et al. 1994). These include AcrA of Enterobacter aerogenes with $68 \%$ identity (Pradel and Pagès 2002), AcrA of Escherichia coli with $65 \%$ identity (Ma et al. 1993), MexA of P. aeruginosa with $52 \%$ identity (Poole et al. 1993), TtgA of P. putida 
with 50\% identity (Ramos et al. 1998), and IfeA of A. tumefaciens with $35 \%$ identity (Palumbo et al. 1998). Based on substantial similarity in nucleotide sequences and the gene arrangement of acrA and $a c r B$ in E. amylovora to the respective genes in Escherichia coli, we assume that these genes are organized in an operon in E. amylovora.

The $a c r R$ gene, divergently transcribed from $a c r A$, encodes a protein of 212 amino acids with a predicted molecular mass of $24.2 \mathrm{kDa}$. AcrR shows similarity to many known or putative members of the TetR family of bacterial transcriptional repressor proteins (Aramaki et al. 1995). This similarity is especially pronounced at the $\mathrm{N}$-terminal end composing the predicted helix-turn-helix DNA-binding motif (data not shown). Ma and associates (1995) suggested that AcrR is a repressor of acrAB expression. Our results clearly indicate that AcrA and AcrB from E. amylovora belong to the MFP and RND superfamily, respectively, and that this transporter complex is significantly homologous to the major efflux pump, AcrAB, from Escherichia coli.

\section{Heterologous expression of $a c r A B$ in Escherichia coli KAM3.}

To address the role of E. amylovora AcrAB in drug resistance, the genes were heterologously expressed in Escherichia coli KAM3, which is hypersensitive to many drugs due to deficiency of the major multidrug efflux pump AcrAB (Morita et al. 1998). The drug susceptibilities of the uncomplemented control strain, KAM3, and of KAM3 (pBBR.acr2) harboring the acr $A B$ region of E. amylovora, are shown in Table 1. Toward plant secondary metabolites like the alkaloid berberine, particularly known from the plant family Berberidaceae, and the flavonoid phloretin occurring as phytoalexin in apple, KAM3 (pBBR.acr2) was eightfold more resistant than the control. The minimal inhibition concentrations (MIC) of methylene blue, crystal violet, and ethidium bromide in KAM3 (pBBR.acr2) were $\approx 16-, 30$ - and 15-fold higher than the control. It was found that $a c r A B$ of $E$. amylovora conferred a twofold increased resistance toward the aminoglycoside kanamycin, the $\beta$-lactam ampicillin, the hydrophilic quinolon nalidixic acid, and the hydrophobic quinolon norfloxacin. Thus, AcrAB of E. amylovora is responsible for multidrug resistance and shows a substrate specificity profile comparable to that previously reported for AcrAB of Escherichia coli (Nishino and Yamaguchi 2001; Okusu et al. 1996; Sulavik et al. 2001). From an ecological point of view, it is especially interesting that the

Table 1. Susceptibilities of Escherichia coli strains to different compounds $^{\mathrm{a}}$

\begin{tabular}{lccc}
\hline & \multicolumn{3}{c}{ MIC $(\boldsymbol{\mu g} / \mathbf{m l})$} \\
\cline { 2 - 4 } Compound & TG1 $^{\mathbf{b}}$ & KAM3 $^{\mathbf{c}}$ & KAM3 (pBBR.acr2) \\
\hline Phloretin & $>1,000$ & 62.5 & 500 \\
Berberine & $>1,000$ & 62.5 & 500 \\
Crystal violet & 12.5 & 0.2 & 6.3 \\
Methylene blue & 500 & 3.1 & 50 \\
Ethidium bromide & 125 & 4 & 62.5 \\
Norfloxacin & 0.1 & 0.02 & 0.05 \\
Nalidixic acid & 6.3 & 1.6 & 3.1 \\
Ampicillin & 3.1 & 1.6 & 3.1 \\
Kanamycin & 1.6 & 0.8 & 1.6 \\
SDS & $>5,000$ & 156 & $>5,000$ \\
\hline
\end{tabular}

${ }^{a}$ Minimal inhibition concentrations (MIC) determination by the microdilution assay in Mueller-Hinton broth was repeated at least three times in each case, and consistencies of MICs were confirmed.

${ }^{\mathrm{b}}$ TG1 is the wild type of mutant KAM3.

${ }^{\mathrm{c}}$ No change in the MIC occurred for mutant KAM3 when the host was transformed with the vector $\mathrm{pBBR} 1 \mathrm{MCS}$ alone.

${ }^{\mathrm{d}}$ Carries the acrAB region of Erwinia amylovora. transporter complex of the plant pathogen mediated resistance against the phytoalexin phloretin from apple.

\section{Generation and genotypic analysis of $a c r B$-deficient mutants.}

To determine the role of the AcrAB transport system in $E$. amylovora during the infection process and the development of fire blight, an $a c r B$-deficient mutant was generated by marker exchange mutagenesis using the suicide plasmid pCAM.acrB$\mathrm{Km}$. PCR was used to confirm integration of the kanamycin $(\mathrm{Km})$-resistance cassette in the genomic $a c r B$ locus. A 3-kb PCR product was detected for the wild-type gene when amplified with the primers acrB_Ea_fwd and acrB_Ea_rev. PCR analysis of $\mathrm{Ap}^{\mathrm{s}} \mathrm{Km}^{\mathrm{r}}$ transformants revealed a lack of the 3-kb signal, suggesting that the $a c r B$ gene of these transformants was inactivated by homologous recombination. Verification of the PCR results was achieved by Southern blot analyses (Fig. 2). For this, genomic DNA of four transformants was digested with BamHI and was hybridized with DNA probes containing $a c r B$, the Km-resistance cassette, and pCAM-MCS, respectively. The signal of the $a c r B$-probe was shifted in the transformants (i.e., mutant Ea1189-3) by $0.1 \mathrm{~kb}$, which represents a replacement of the internal SacII fragment of $a c r B$ (Fig. 1) by the inserted $\mathrm{Km}$-cassette which, thereby, had replaced part of the deleted $a \mathrm{crB}$ sequence (see Materials and Methods). The Kmprobe highlighted a single DNA fragment and the pCAMMCS-probe failed to hybridize, indicating that, in the mutants, the native alleles were replaced by double crossover.

\section{Phenotypic analysis of $a c r B$-deficient mutants.}

E. amylovora mutant Ea1189-3 disrupted in acrB was chosen for further phenotypic characterization. Determination of MIC of various antibiotics and toxins was used to examine the susceptibility of Ea1189-3 compared with the parent strain (Table 2). The mutant was susceptible to tetracycline with an 8 fold reduction in the MIC, and to the hydrophobic fluoroquinolon derivatives norfloxacin and ciprofloxacin with a 10-fold reduction in the MIC. In contrast to the wild type, the mutant was sensitive to the $\beta$-lactam antibiotics ampicillin and carbenicillin. In addition, the mutant showed increased susceptibility to the detergent sodium dodecyl sulfate and to the dyes crystal violet, methylene blue, and ethidium bromide. The MIC of the aminoglycoside spectinomycin and the hydrophilic quinolon nalidixic acid did not differ from those determined for the wild type (data not shown). Complementation of Ea1189-3 with plasmid pBBR.acr2 restored resistance comparable to the parent strain, with the exception of the $\beta$-lactams, suggesting that these antibiotics are no substrates of the AcrAB efflux system (Table 2). Our data suggested that the mutation of $a c r B$ in

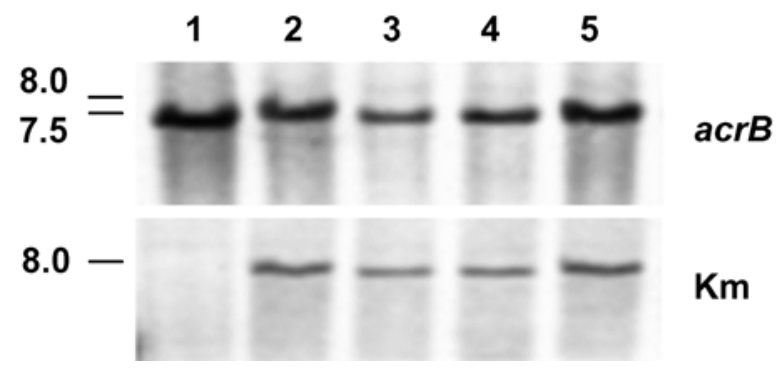

Fig. 2. Southern blot analysis of Erwinia amylovora insertion mutants. BamHI-digested genomic DNA was hybridized with a 3.0-kb acrB-probe and a $1.7-\mathrm{kb}$ probe containing the kanamycin $(\mathrm{Km})$-resistance cassette, respectively. Lane 1, Ea1189 (wild type); lane 2, Ea1189-1; lane 3, Ea1189-2; lane 4, Ea1189-3; lane 5, Ea1189-4. The hybridization patterns indicated that the mutants had replaced there native alleles by double crossover. 
Ea1189-3 resulted in hypersusceptibility to toxic lipophilic and amphiphilic compounds, further substantiating the genotypic characterization of the mutant.

\section{HR assay on tobacco.}

Hypersensitive response (HR), a rapid localized necrosis of plant tissue at the site of the pathogen infection, represents one of the plant defense mechanisms (Lam et al. 2001). The ability of a plant pathogen to elicit the HR on nonhost plants and to be pathogenic on host plants is controlled by HR and pathogenicity genes $(\mathrm{hrp})$. The characteristic phenotype associated with hrp mutants is the inability to cause disease in a compatible interaction, as well as the inability to elicit the HR during incompatible interactions.

Tobacco, a nonhost plant of the fire blight pathogen, was used to test if the mutation of $a c r B$ in E. amylovora impaired the function of hrp gene products. Ea1189-3 and the parent strain were inoculated simultaneously on one tobacco leaf and the development of the HR was monitored after $24 \mathrm{~h}$. Both mutant and wild type elicited a visible HR to the same degree (data not shown). This demonstrated that the hrp regulon remained unaffected in mutant Ea1189-3.

\section{Contribution of the multidrug efflux transporter AcrAB to virulence of $E$. amylovora.}

The impact of AcrAB on virulence of the fire blight pathogen was evaluated on apple rootstock MM 106 by means of the development of disease symptoms and on the basis of monitoring the establishment of a bacterial population $24 \mathrm{~h}$ post inoculation (hpi). For virulence assays, shoot tips from 15 apple plants were inoculated by the prick technique (May et al. 1997). This technique mimics the natural infection process, in which pathogens often enter the plant through open wounds. One advantage of this method is the ability to inoculate a defined number of bacterial cells on the pinpricked wounds. Ea1189-3 and the parent strain were inoculated simultaneously on one plant providing identical growth conditions.

To assess the development of fire blight symptoms, 15 apple shoots were inoculated with the mutant and wild type, respectively, in three additional experiments with five plants each. After 3 weeks of incubation, only 1 of 15 shoots inoculated with mutant Ea1189-3 exhibited typical disease symptoms such as ooze formation, necrosis, and the shepherd's

Table 2. Susceptibilities of Erwinia amylovora strains to different compounds $^{\mathrm{a}}$

\begin{tabular}{|c|c|c|c|}
\hline \multirow[b]{2}{*}{ Compound } & \multicolumn{3}{|c|}{ MIC $(\mu \mathrm{g} / \mathrm{ml})$} \\
\hline & Ea1189 & Ea1189-3 ${ }^{b}$ & Ea1189-3 (pBBR.acr2) \\
\hline Phloretin & 250 & 16 & 125 \\
\hline Quercetin & $>1,000$ & 31 & $>1,000$ \\
\hline Naringenin & 500 & 31 & 250 \\
\hline (+)-Catechin & 5,000 & 1,250 & 2500 \\
\hline Berberine & $>1,000$ & 31 & $>1,000$ \\
\hline Norfloxacin & 0.2 & 0.02 & 0.2 \\
\hline Tetracycline & 1.6 & 0.2 & 1.6 \\
\hline Ampicillin & 63 & 6.3 & 16 \\
\hline Carbenicillin & 63 & 6.3 & 6.3 \\
\hline Methylene blue & $>500$ & 12.5 & $>500$ \\
\hline Crystal violet & 3.1 & 0.4 & 3.1 \\
\hline Ethidium bromide & 250 & 1.6 & 250 \\
\hline SDS & 250 & 4 & 250 \\
\hline \multicolumn{4}{|c|}{$\begin{array}{l}\text { a Minimal inhibition concentrations (MIC) determination by the } \\
\text { microdilution assay in asparagine minimal medium } 2 \text { was repeated at } \\
\text { least three times in each case, and consistencies of MICs were } \\
\text { confirmed. } \\
\text { b No change in the MIC occurred for the } a c r B \text { mutant when the host was } \\
\text { transformed with the vector pBBR1MCS alone. }\end{array}$} \\
\hline
\end{tabular}

crook-like bending of the shoot tip. In contrast, inoculation of the Ea1189 wild type led to nine shoots which exhibited typical fire blight symptoms. This result suggested that the AcrAB transport system plays an important role during host plant colonization as a resistance mechanism against plant defense. This assumption was corroborated by determination of the establishment of bacterial populations $24 \mathrm{hpi}$. Mutant Ea1189-3 and its parent strain were inoculated at different cell numbers $\left(10^{2}\right.$ to $10^{6} \mathrm{CFU} /$ inoculation site $)$. Fifteen shoot-tips were used for each bacterial concentration. At 24 hpi, bacterial multiplication was monitored by re-isolating bacterial cells from infected plant tissue (Table 3). After inoculation of the $a c r B$ mutant with low cell numbers $\left(10^{2}\right.$ and $10^{3} \mathrm{CFU} /$ prick), multiplication of the bacteria was not detectable. Inoculation numbers of $>10^{4} \mathrm{CFU}$ per prick were necessary for a successful re-isolation of mutant cells. Moreover, the population decreased approximately 100-fold compared with the initially inoculated cell numbers, indicating that that Ea1189-3 was clearly impaired in multiplication in the tissue of MM 106. In contrast, the wild type reached an approximately 10-fold increased population density compared with the initially inoculated cell numbers of $10^{2}$ to $10^{5} \mathrm{CFU} /$ prick. Results of these experiments indicated that AcrAB appears to be a protein complex required for virulence of E. amylovora, presumably by preventing accumulation of antimicrobial plant-borne compounds in the bacterial cell.

\section{Susceptibility toward leaf extracts.}

One strategy of plants to defend themselves against pathogenic microbes is the production of low molecular weight, antimicrobial compounds termed phytoalexins. After challenging plants with pathogens, phytoalexins either are synthesized de novo or released as toxic compounds from glycosides stored in plant cell vacuoles (Osbourn 1996). For members of the family Rosaceae, no evidence of plant inhibitor induction in response to E. amylovora infection has been provided thus far. However, a constitutive level of isoflavonoids, which often exhibit antimicrobial activity, is distributed widely within this plant family (Grayer and Kokubun 2001; Harborne 1999).

To confirm the existence of such compounds in apple rootstock MM 106, leaf tissue was extracted by methanol. The crude extracts were examined in agar diffusion assays with Ea1189-3 and its parent strain as test organisms. Clear inhibition zones of $25 \mathrm{~mm}$ in diameter and partial inhibition zones of $45 \mathrm{~mm}$ in diameter were observed (Fig. 3). Extracts from MM 106 significantly inhibited growth of the $a c r B$ mutant compared with the wild type. Leaf samples from MM 106 infected with E. amylovora and unchallenged MM 106 exhibited the same growth-inhibiting effect on Ea1189-3. Moreover, when the complemented mutant Ea1189-3 (pBBR.acr2) was used as the test organism, the inhibitory effects of MM16 tissue extracts were negligible and resembled those of the wild type (data not shown). Thus, this apple rootstock tissue synthesizes

Table 3. Virulence assay on apple rootstock MM106 (CFU/shoot)

\begin{tabular}{lll}
\hline & \multicolumn{2}{c}{ Re-isolated bacteria cells $^{\mathbf{a}}$} \\
\cline { 2 - 3 } Inoculum $^{\mathbf{b}}$ & \multicolumn{1}{c}{ Ea1189 } & \multicolumn{1}{c}{ Ea1189-3 $^{-129}$} \\
\hline $10^{2}$ & $6.0 \times 10^{2} \pm 60$ & 0 \\
$10^{3}$ & $4.0 \times 10^{4} \pm 1.3 \times 10^{3}$ & 0 \\
$10^{4}$ & $5.0 \times 10^{5} \pm 6.5 \times 10^{3}$ & $2.8 \times 10^{2} \pm 63$ \\
$10^{5}$ & $9.0 \times 10^{5} \pm 7.5 \times 10^{4}$ & $4.0 \times 10^{3} \pm 4.2 \times 10^{2}$ \\
$10^{6}$ & $1.3 \times 10^{6} \pm 5.2 \times 10^{6}$ & $4.8 \times 10^{4} \pm 1.2 \times 10^{3}$ \\
\hline
\end{tabular}

${ }^{\text {a }}$ Establishment of a population of Erwinia amylovora Ea1189 and acrB mutant was determined $24 \mathrm{~h}$ post inoculation. Data represent the average CFU numbers from 15 individual plants.

${ }^{\mathrm{b}}$ Bacteria were inoculated by prick technique in the shoot tip. 
constitutive antimicrobial metabolites which appear to be substrates of the multidrug efflux pump AcrAB of E. amylovora.

\section{Susceptibility of Ea1189 toward phytoalexins from apple.}

Resulting from virulence tests and agar diffusion assays with leaf extracts, the AcrAB multidrug efflux pump in E. amylovora presumably plays a role in resistance of the pathogen toward phytoalexins. To substantiate this hypothesis, we examined as substrates of AcrAB different isoflavonoids which were reported to be widely distributed phytoalexins in members of Rosaceae (Grayer and Kokubun 2001; Harborne 1999). Particularly, we tested the susceptibilities of Ea1189-3 and its parent strain to different isoflavonoids previously identified and isolated from apple tissue (Treutter 2001).

In the $a c r B$ mutant, MICs of the dihydrochalcone phloretin, the flavonol quercetin, the flavanone naringenin, and the monomeric flavanol (+)-catechin, were decreased 16-, 32-, 16-, and 2-fold, respectively, compared with the parent strain (Table 2). Again, complementation of the mutant with plasmid pBBR.acr2 completely restored resistance toward the tested isoflavonoids, confirming that these compounds are substrates of the AcrAB efflux system in the fire blight pathogen. Additionally, the mutant showed wild-type levels of resistance to the hydroxycinnamic acid derivative, chlorogenic acid and the benzoic acid derivative, protocatechuic acid. Phloridzin, the glycoside of phloretin, did not cause growth inhibition of either the mutant or the wild type (data not shown). The phytoalexins identified as substrate of AcrAB in E. amylovora are hydrophobic compounds. This corresponds to the chemical properties of the substrates recognized above. Our results strongly suggest that the lack of the transporter results in reduced virulence of the $a \operatorname{cr} B$ mutant on apple rootstock MM 106 due to the accumulation of antimicrobially active phytoalexins in the bacterial cells.

\section{Promoter activity of $a c r A B$ and $a c r R$ in vitro.}

The importance of plant signals for the regulation of different virulence factors of phytopathogens has been well established (van Gijsegem 1997). The above results prompted us to investigate whether the phytoalexins identified as substrate of the transport system AcrAB affect the gene expression of acr$R A B$ in E. amylovora. To address this question, the regulation of $a c r R$ and of the divergently orientated $a c r A B$ operon was analyzed by generating transcriptional fusions to the egfp reporter gene coding for enhanced green fluorescent protein (EGFP). Two plasmids, designated pBBR.egfp.acrA and pBBR.egfp.acrR, were constructed. They contain the promoter region of $a c r R$ and $a c r A B$, respectively, upstream of the egfp gene resulting in transcriptional fusions. These plasmids were transformed into E. amylovora wild type and EGFP fluorescence was determined in the absence or presence of various substrates of AcrAB. It is important to mention that substrate concentrations, which do not inhibit bacterial growth, were tested in these assays.

Initially, it was tested whether the bacterial growth phase influenced the transcription of $a c r A B$ or $a c r R$ (Fig. 4). In $E s$ cherichia coli, a 2.5-fold increased transcription of $a c r A B$ was reported during the onset of stationary-phase growth (Ma et al. 1995). In E. amylovora, the promoter activity of $a c r A B$ and acrR was increased approximately 2.5- and 3-fold, respectively, in the stationary phase (Fig. 4).

Next, we studied the impact of diverse antimicrobial compounds on $a c r A B$ and $a c r R$ expression. The promoter activity of $a c r A B$ was increased by the addition of naringenin $(8 \mu \mathrm{g} / \mathrm{ml})$ and phloretin $(4 \mu \mathrm{g} / \mathrm{ml})$ approximately 1.5 -fold and 2 -fold, respectively (Fig. 5A). The promoter activity of acrR was increased approximately 1.5 -fold by the addition of naringenin ( 8 $\mu \mathrm{g} / \mathrm{ml}$ ) but was not induced by phloretin (Fig. 5B). The levels of transcription of $a c r A B$ and $a c r R$ were not affected by the addition of quercetin, berberine, norfloxacin, and crystal violet over the concentration range tested.

\section{Promoter activity of $a c r A B$ and $a c r R$ in planta.}

To study the activity of the $a c r A B$ and $a c r R$ promoters in planta, Ea1189 transformants harboring pBBR.egfp.acrA and pBBR.egfp.acrR were inoculated into apple rootstock MM 106 and re-isolated after different time periods of incubation. EGFP fluorescence of the re-isolated bacteria was compared with the fluorescence of cells grown in minimal medium and harvested at the stationary phase, at which maximal promoter activity occurred. EGFP fluorescence of bacteria was quantified by confocal laser scanning microscopy.

In re-isolated bacteria, activity of the $a c r A B$ promoter was detected 1,3 , and 4 days after inoculation. Within this incubation period, all re-isolated samples exhibited the same amount of fluorescence. Compared with the cells grown in liquid cul-
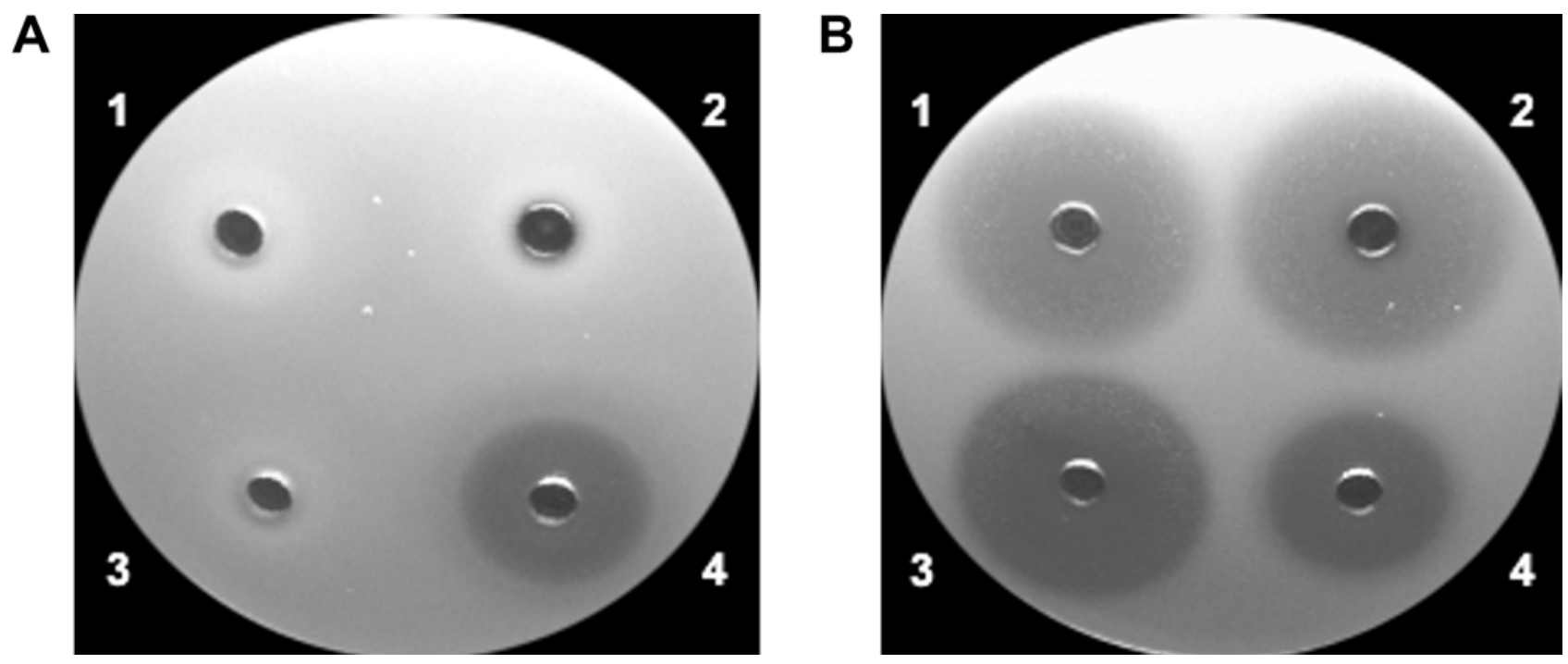

Fig. 3. Antimicrobial activity of leaf extracts of apple rootstock MM106 in agar plate diffusion assay. A, Erwinia amylovora Ea1189 wild type used as the test organism and B, growth inhibition of mutant Ea1189-3 by apple leaf extracts. 1, extract from unchallenged plants; 2, extract from plants infected with E. amylovora (3 days after inoculation); 3, extracts from plants infected with $E$. amylovora (30 days after inoculation); 4 , spectinomycin (5 $\mu \mathrm{g} / \mathrm{ml})$. 
ture, the activity of the $\operatorname{acr} A B$ promoter of re-isolated bacteria was increased 1.5- to 2-fold (Fig. 6). Due to the weak promoter activity of acrR, the fluorescence of EGFP was hardly detectable in cells from the liquid culture and undetectable in re-isolated bacteria harboring pBBR.egfp.acrR. These results suggested that $a c r A B$ is inducible in planta, whereas $a c r R$ expression seems to be very low in E. amylovora cells infecting its host plant.

\section{Distribution of acrB among $E$. amylovora strains} and related plant-associated bacteria.

Multidrug efflux proteins are ubiquitously distributed among prokaryotes. E. amylovora belongs to the family Enterobacteriaceae. Formerly, acrB-like genes were identified in human pathogenic members of this family (i.e., in the genera $E s$ cherichia, Shigella, Salmonella, Klebsiella, Enterobacter, and Yersinia) (Paulsen et al. 2001). To determine if $a c r B$ is also present in different plant-pathogenic enterobacteria, PCR and Southern blot analyses were conducted. The acrB-specific primers acrB_Ea_fwd and acrB_Ea_rev were used to amplify a PCR product from genomic DNA of 19 E. amylovora strains. All tested strains showed a approximately 3-kb signal regardless of the geographic origin of the isolates (Table 4). PCR with samples of representative strains from related plant-associated species did not yield any detectable amplification, possibly due to the specificity of the PCR method. In contrast, Southern blot analysis at low stringency revealed the occur-
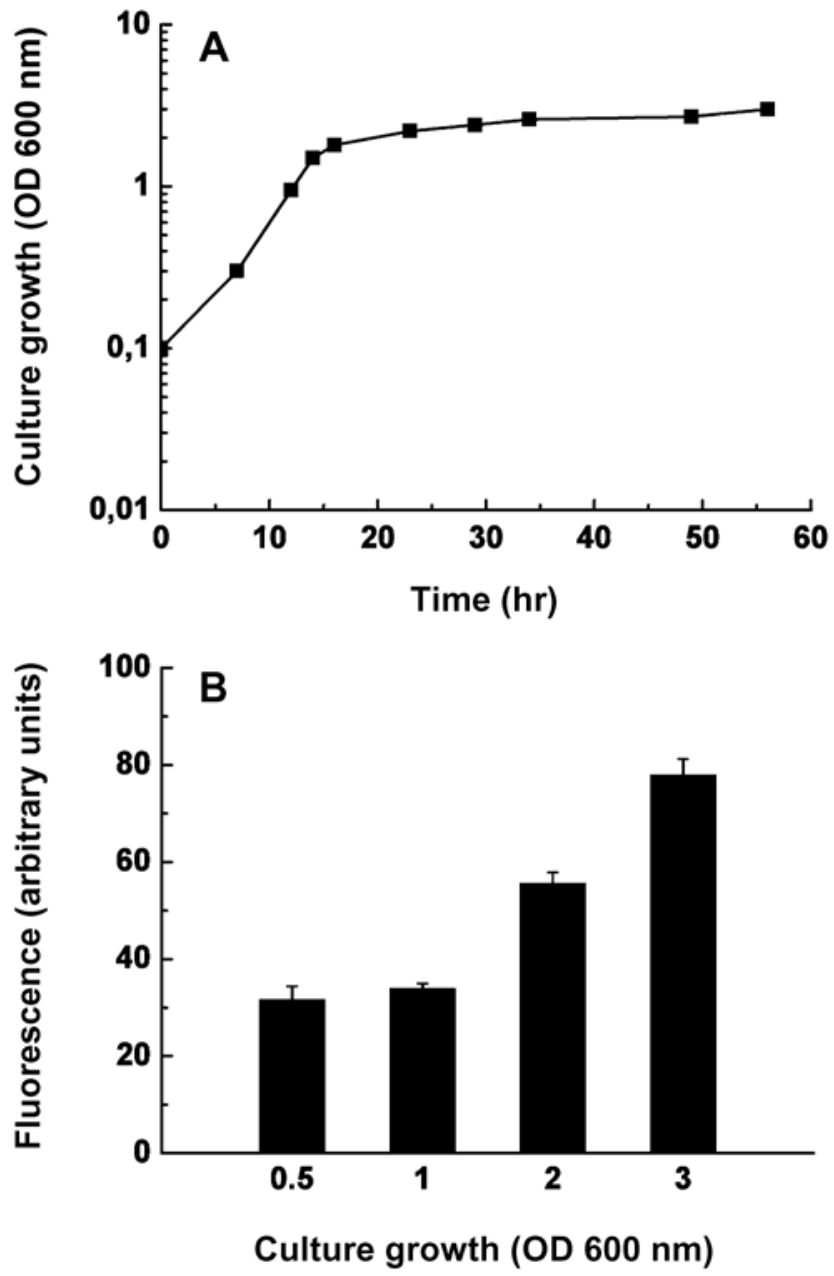

rence of $a c r B$ homologues in strains of all six tested Erwinia spp. Furthermore, the $a c r B$ probe hybridized with genomic DNA from nine tested strains of the genera Pantoea, Pectobacterium, and Brenneria, which are phylogenetically related to Erwinia (Hauben et al. 1998) (Table 4). These results suggest that the AcrB transport protein is distributed widely within human- and plant-pathogenic enterobacteria.

\section{DISCUSSION}

In this study, we investigated the influence of a putative RND-type multidrug efflux transporter, AcrB, on pathogenesis of the fire blight agent, E. amylovora.

In gram-negative bacteria, RND-type transporters are located in the inner membrane and function in concert with accessory proteins belonging to the MFP family (Dinh et al. 1994) and the outer membrane factor (OMF) family (Paulsen et al. 1997). These tripartite transport systems enable drug efflux across both membranes (Zgurskaya and Nikaido 2000). In $E$. amylovora, acrB encodes the RND-type protein and acrA the accessory MFP. We assumed that acrA and acrB form an operon in E. amylovora, based on the significant sequence homology and the genetic organization which is similar to that of the acrAB genes in Escherichia coli (Ma et al. 1993). Obviously, a gene encoding an OMF component is not located in the same gene cluster and has yet to be discovered. In Escherichia coli, AcrAB recruits the separately expressed OMF
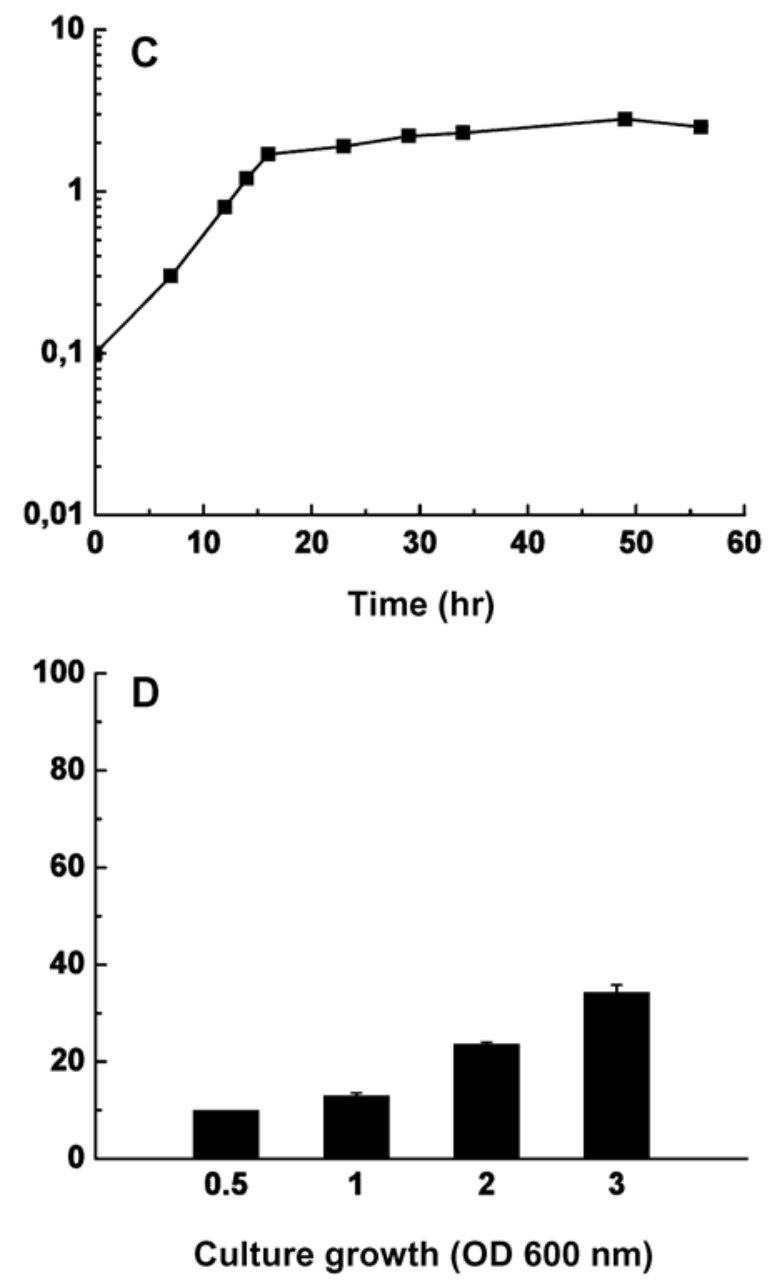

Fig. 4. Promoter activities of $a c r A B$ and $a c r R$ from Erwinia amylovora as determined by transcriptional fusions with the reporter gene egfp. E. amylovora wild type was transformed with pBBR.egfp.acrA $\left(a c r A^{\prime}-e g f p^{+}\right)$and pBBR.egfp.acrR $\left(a c r R^{\prime}-e g f p^{+}\right)$. Fluorescence of enhanced green fluorescent protein was measured in the course of growth in liquid AMM2; OD, optical density. A, Growth kinetic of Ea1189 (pBBR.egfp.acrA); B, fluorescence of Ea1189 (pBBR.egfp.acrA); C, growth kinetic of Ea1189 (pBBR.egfp.acrR); and D, fluorescence of Ea1189 (pBBR.egfp.acrR). 
TolC (Fralick 1996). This OM channel operates with several transport systems; a feature that appears to be characteristic to Escherichia coli. In other gram-negative bacteria, individual OM channels often are unique for each transporter and expressed in the same gene cluster, such as OprJ, OprM, and OprN in Pseudomonas aeruginosa (Koehler et al. 1997; Li et al. 1995; Poole et al. 1993) and MtrE in Neisseria gonorrhoeae (Hagmann et al. 1995).

Given the sequence homology to AcrAB of Escherichia coli as multidrug efflux pump, the substrate spectrum of AcrAB in E. amylovora was examined. AcrAB mediated resistance toward hydrophobic and amphiphilic antibiotics, dyes, and a detergent, comparable with the previously reported broad-substrate spectrum of AcrAB from Escherichia coli and other homologous multidrug efflux pumps (Nishino and Yamagushi 2001; Poole 2000; Sulavik et al. 2001). It did not provide protection against the tested $\beta$-lactam antibiotics, with their drug targets located in the periplasmic space, and against the tested hydrophilic aminoglycosides.

In plant pathogens, multidrug efflux transporter may function in protection against phytoalexins, which represent an important plant defense mechanism. Particularly, studies on phytopathogenic fungi indicated that multidrug resistance transporters contribute to virulence by reducing the toxic effect of phytoalex-
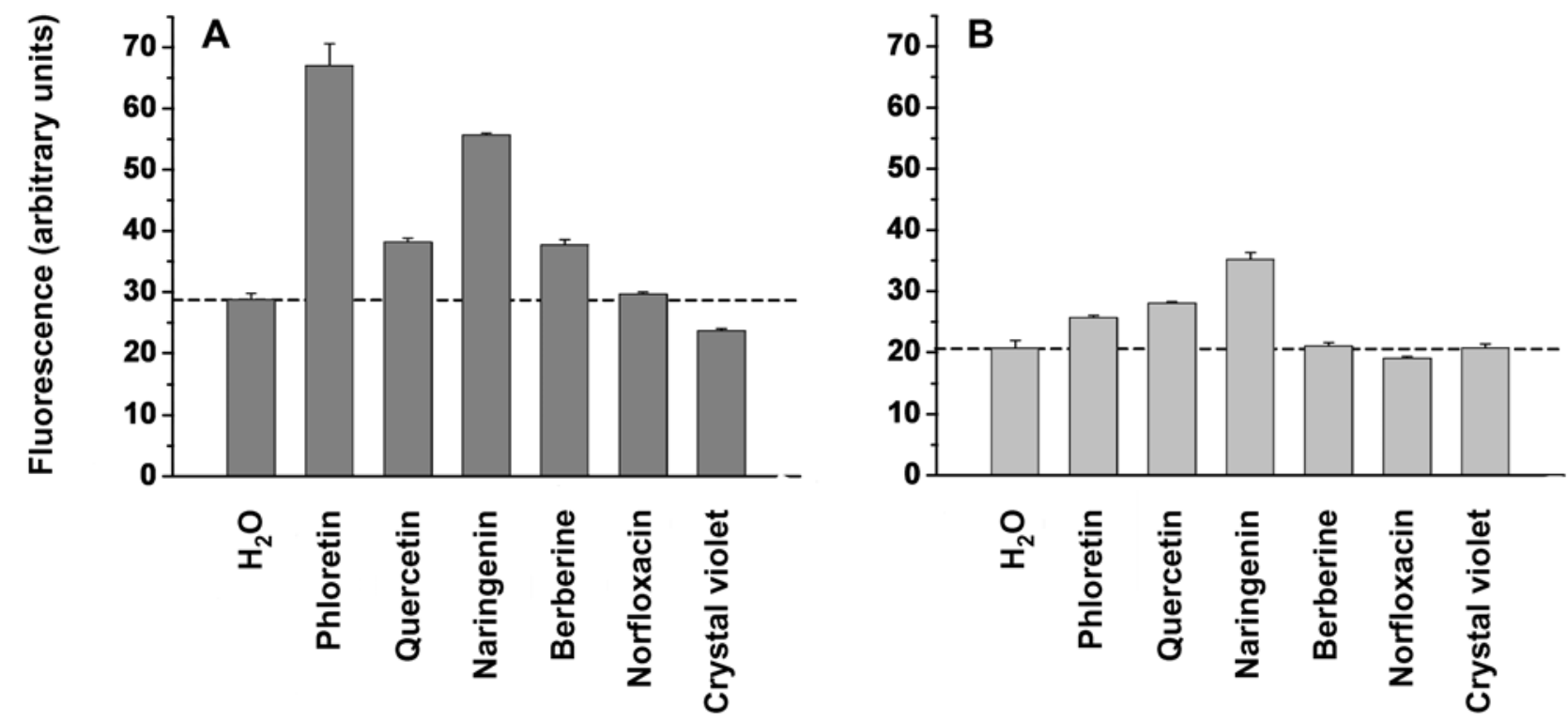

Fig. 5. Promoter activities of acrAB and acrR from Erwinia amylovora as determined by transcriptional fusions with the reporter gene egfp. E. amylovora wild type was transformed with pBBR.egfp.acrA and pBBR.egfp.acrR, respectively. Fluorescence of enhanced green fluorescent protein was measured after $24 \mathrm{~h}$ of incubation of the bacteria with transporter substrates. A, Ea1189 (pBBR.egfp.acrA); B, Ea1189 (pBBR.egfp.acrR). Phloretin, $4 \mu \mathrm{gg} / \mathrm{ml}$; quercetin, $8 \mu \mathrm{g} / \mathrm{ml}$; naringenin, $8 \mu \mathrm{g} / \mathrm{ml}$; berberine, $31 \mu \mathrm{g} / \mathrm{ml}$; norfloxacin, $0.03 \mu \mathrm{g} / \mathrm{ml}$; crystal violet, $0.3 \mu \mathrm{g} / \mathrm{ml}$.
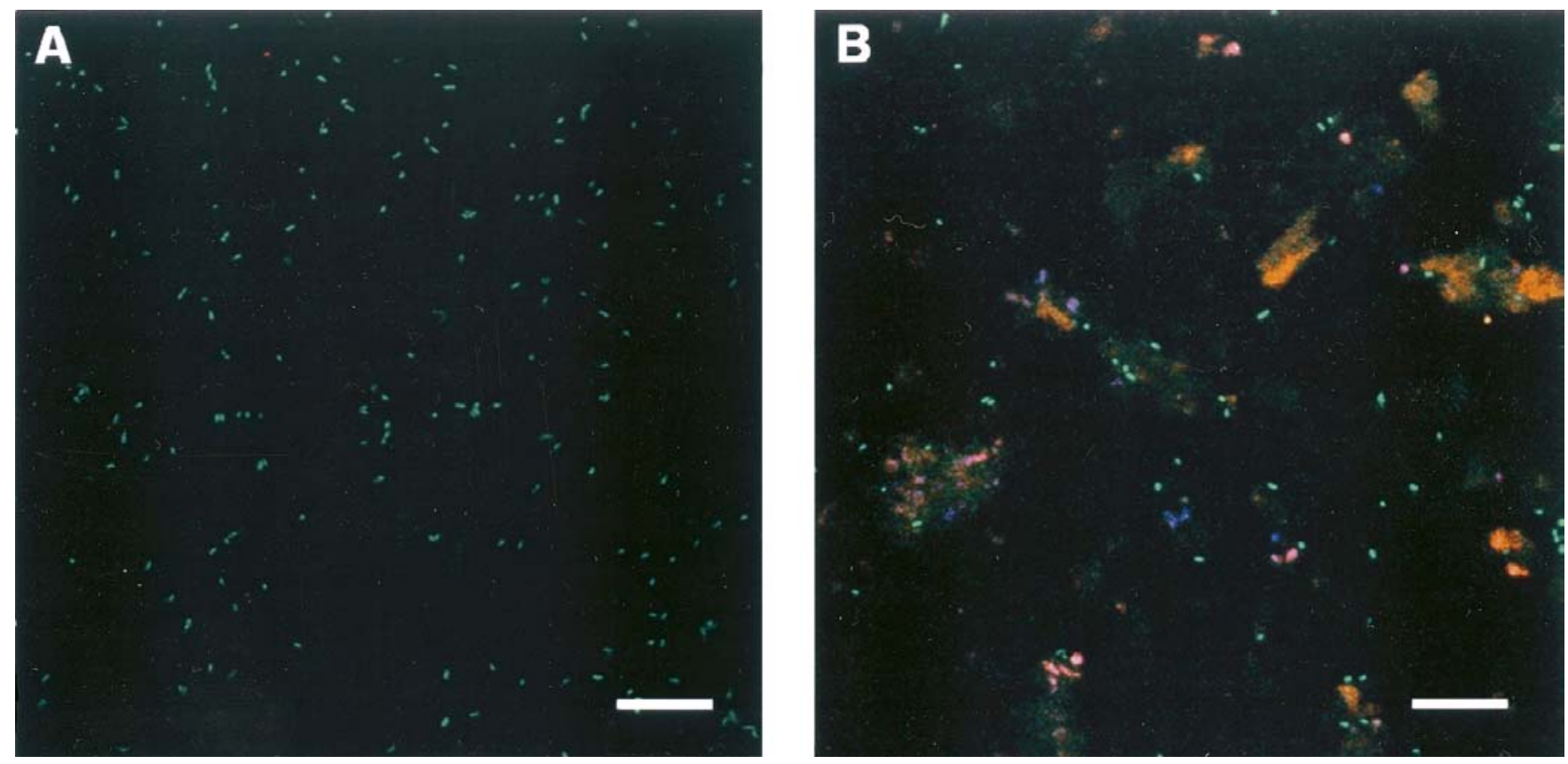

Fig. 6. Fluorescence of Erwinia amylovora wild type harboring pBBR.egfp.acrA as imaged by confocal laser scanning microscopy. A, Ea1189 (pBBR.egfp.acrA) cultivated in asparagine minimal medium 2 and harvested in the stationary growth phase. B, Ea1189 (pBBR.egfp.acrA) re-isolated from apple rootstock MM106 3 days after inoculation. 
ins (Del Sorbo et al. 2000). Best characterized examples are the ABC transporters, BcatrB and Gpabc1. Schoonbeek and associates (2001) demonstrated impaired virulence of BcatrBnegative $B$. cinerea mutants on grapevine and the increase of sensitivity to the grapevine phytoalexin resveratrol. In G. pulicaris, mutation of $G p a b c 1$ reduced tolerance to the potato phytoalexin rhisitin as well as virulence on potato tubers (Fleißner et al. 2002). Few data are available about transporters conferring multidrug resistance in phytopathogenic bacteria and their role in the plant-microbe interaction. Palumbo and associates (1998) studied the RND-type transport system IfeAB in the causal agent of crown gall tumors, Agrobacterium tumefaciens. Inoculation of an ifeA mutant resulted in colonization densities on alfalfa roots comparable with that of the parent strain; however, this mutant was impaired in competition against the wild type. The MFS-type efflux pump RmrAB in the nitrogen-fixing symbiont Rhizobium etli mediates resistance toward legume phytoalexins and was demonstrated to be involved in nodule formation (Gonzáles-Pasayo and Martinez-Romero 2000).

In the current article, we demonstrate for the first time that the disruption of a multidrug efflux pump in a plant-pathogenic bacterium resulted in a dramatically reduced virulence. The acrB mutant of $E$. amylovora was significant impaired in survival after inoculation into apple plantlets. After $24 \mathrm{~h}$ of growth in the shoot tissue, cells of the parent strain multiplied approximately 10 -fold, whereas only $1 \%$ of the inoculated $\operatorname{acr} B$-deficient cells survived. Moreover, inoculation of 15 apple shoots with $\operatorname{acr} B$-deficient bacteria led to the development of fire blight symptoms in only a single case. In contrast, the wild type created severe symptoms in two-thirds of all inoculated shoots. Plants obviously were able to circumvent the infection by $a c r B$-deficient bacteria, presumably due to the production of phytoalexins. The AcrAB transport system in E. amylovora seems to play an important role in resistance against plantderived antibacterial toxins and, thus, in colonization of the plant. It is tempting to speculate that Acr AB might enable the bacteria to outgrow the infection site in which chemicals of plant defense accumulate. In the mutant, lack of phytoalexin efflux may result in a growth arrest of the bacteria mediated by the toxic effects of the phytoalexins. Consequently, the host plant may further restrict the growth of the bacteria by activating additional defense reactions.

To prove the presence of antimicrobial secondary metabolites synthesized by apple plantlets, leaf tissue was extracted and applied to bacterial test cultures. Extracts caused significant growth inhibition of the $a c r B$ mutant, but not of the parent strain. Leaf extracts from plants previously infected with $E$. amylovora and unchallenged plants exhibited the same inhibitory effect. This suggests a constitutive occurrence of antibacterial metabolites in apple rootstock MM 106. The chemical nature of those remains to be identified in future studies.

Phytoalexin responses of host plants toward E. amylovora infection have not been determined in previous studies. However, a wide distribution of constitutively synthesized isoflavonoids among members of the Rosaceae family has been described (Grayer and Kokubun 2001; Harborne 1999). In our study, we examined the antibiotic effects of various compounds previously described for apple plants (Treutter 2001). Phloretin, quercetin, (+)-catechin, and naringenin inhibited growth of the $a c r B$ mutant significantly more than growth of

Table 4. Polymerase chain reaction (PCR) and Southern blot screening for acrB alleles in Erwinia amylovora strains and related plant-associated species

\begin{tabular}{|c|c|c|c|}
\hline \multirow[b]{2}{*}{ Strain } & \multicolumn{3}{|c|}{ Southern } \\
\hline & PCR & blot $^{\mathbf{a}}$ & Source $^{b}$ \\
\hline \multicolumn{4}{|l|}{ Erwinia amylovora } \\
\hline GSPB1189 & + & + & GSPB \\
\hline GSPB1190, GSPB1263, GSPB1654, GSPB1655, GSPB1656, GSPB1657, GSPB1658, GSPB1659, GSPB1839 & + & ND & GSPB \\
\hline $\mathrm{Ea} 0, \mathrm{Ea} 1, \mathrm{Ea} 1 / 79, \mathrm{Ea} 8, \mathrm{Ea} 11, \mathrm{Ea} 266, \mathrm{PD} 576, \mathrm{PD} 579, \mathrm{IL6}$ & + & ND & K. Geider \\
\hline E. pyrifoliae Ep1/96 & - & + & K. Geider \\
\hline E. rhapontici DSM4484 & - & + & F. Boernke \\
\hline E. rhapontici GSPB454 & - & + & GSPB \\
\hline E. persicinus CFBP3622 & - & + & K. Geider \\
\hline E. persicinus GSPB 2443 & - & + & GSPB \\
\hline E. mallotivora $\mathrm{CFBP} 2503$ & - & + & K. Geider \\
\hline E. psidii CFBP3627 & - & + & K. Geider \\
\hline E. herbicola pv. gypsophilae $824-1$ & - & + & I. Barash \\
\hline Pantoea agglomerans $2 \mathrm{~b} / 89,52 \mathrm{c} / 90$ & - & + & B. Völksch \\
\hline Pantoea stewartii SW2, SS 104 & - & + & D. L. Coplin \\
\hline Pectobacterium chrysanthemi AC 4150, 3937 & - & + & A. Collmer \\
\hline Pectobacterium carotovorum subsp. carotovorum 90 & - & + & B. Völksch \\
\hline Brenneria quercina $\mathrm{CFBP} 3617$ & - & + & K. Geider \\
\hline Brenneria salicis CFBP802 & - & + & K. Geider \\
\hline
\end{tabular}

${ }^{a}$ Southern blot analysis with a hybridization temperature of $55^{\circ} \mathrm{C}$ was carried out using the $E$. amylovora acrB gene amplified by PCR as a DIG-labeled probe; $\mathrm{ND}=$ not determined.

${ }^{\mathrm{b}}$ GSPB $=$ Göttinger Sammlung phytopathogener Bakterien, Göttingen, Germany.

Table 5. Escherichia coli and Erwinia amylovora strains used in this study

\begin{tabular}{|c|c|c|}
\hline Strain & Relevant characteristics & Reverence or source $^{a}$ \\
\hline \multicolumn{3}{|l|}{ Escherichia coli } \\
\hline DH5 $\alpha$ & Supe44 $\Delta$ lacU169 ( $\phi 80$ lacZ $\Delta$ M15) hsdR17 recA1 endA1 gyrA96 thi-1 relA1 & Sambrook and Russel 2001 \\
\hline TG1 & Sube hsd $\Delta 5$ thi $\Delta$ (lac-proAB) $\mathrm{F}^{\prime}\left[\operatorname{traD} 36\right.$ proAB $^{+}$lacl ${ }^{\mathrm{q}}$ lacZ $\left.\bullet \mathrm{M} 15\right]$ & Sambrook and Russel 2001 \\
\hline KAM3 & AcrAB mutant of TG1 & Morita et al. 1998 \\
\hline S17-1 & Thi pro hsdR ${ }^{-}$hsdM $^{+}$recA RP4 2- Tc::MU-Km::Tn7(Tetr/Smr) & Wilson et al. 1995 \\
\hline S17-1 $\lambda$-pir & $\lambda$-pir lysogen of S17-1 & Wilson et al. 1995 \\
\hline \multicolumn{3}{|c|}{ Erwinia amylovora } \\
\hline GSPB1189 & Wild type & GSPB \\
\hline GSPB1189-3 & $\mathrm{Km}^{\mathrm{r}}$, acr $B$ mutant carrying $\mathrm{Km}^{\mathrm{r}}$ cassette in the $\operatorname{acr} B$ gene & This study \\
\hline
\end{tabular}

${ }^{\mathrm{a}} \mathrm{GSPB}=$ Göttinger Sammlung phytopathogener Bakterien, Göttingen, Germany. 
the wild type of Ea1189. Consequently, it can be assumed that these compounds are exported by AcrAB in E. amylovora. Notably, Mayr and associates (1995) found that the glycosides of phloretin and phloridzin, together with quercetin glycosides, represented the quantitatively most important compounds in apple leaves of the cv. Golden Delicious. The glycosides accumulate in plant cell vacuoles and are released as aglycons, developing their toxic activity after pathogen attack.

The AcrAB transport system turned out to be a protein complex required for virulence in E. amylovora which protects the pathogen from naturally occurring phytoalexins. In several bacterial pathosystems, virulence factors are induced by plantderived signals. The promoter activity of acrAB in E. amylovora was 1.5 - and 2-fold increased by the phytoalexins naringenin and phloretin, respectively. Palumbo and associates (1998) reported the induction of the transporter IfeAB in A. tumefaciens by isoflavonoids from alfalfa. However, impact in virulence of IfeAB was not demonstrated in that study and induction of multidrug efflux transporters by phytoalexins has been demonstrated only in fungi. Gpabc1 in G. pulicaris is induced by rhisitin (Fleißner et al. 2002), BcatrB in B. cinerea by resveratrol (Schoonbeek et al. 2001), and ABC1 in Magnaporthe grisea by sakuranetin (Urban et al. 1999). In Escherichia coli, acr $A B$ expression was twofold increased by decanonate, a fatty acid occurring in the natural environment of the enteric bacterium (Ma et al. 1995). As in the later case, the induction of $a \operatorname{cr} A B$ in E. amylovora was rather subtle in the present study, suggesting that this type of transporter might respond only moderately to environmental stimuli.

Usually, expression of multidrug transporters is controlled by specific regulatory proteins, whose genes are often adjacent to those encoding the transport system. This also is true for the acrR gene of E. amylovora, which is transcribed in the opposite direction to the $a c r A B$-operon. Based on sequence similarities to other DNA-binding protein, especially to AcrR from Escherichia coli, we hypothesized that $\operatorname{acr} R$ codes for a protein that represses both its own and $a c r A B$ transcription. Transcription of $a c r R$ was increased by naringenin, in a manner similar to the observed induction of $a c r A B$. However, an induction of $a c r R$ expression by phloretin was not observed, although an increase in $\operatorname{acr} A B$ expression was detected with this substance. It appears that, in Escherichia coli, the principal function of AcrR is to modulate $a c r A B$ expression, thereby preventing excessive production of the AcrAB pump, whereas MarA and related global regulators are responsible primarily for the actual induction of $a c r A B$ (Grkovic et al. 2002; Ma et al. 1996).
Whether this is also the case in E. amylovora remains to be elucidated.

In planta experiments showed that $\operatorname{acr} A B$ is induced twofold during growth of bacteria in apple tissue. This supported our assumption that AcrAB confers ecological benefits during colonization of the host plant. In summary, the presented data demonstrate that a multidrug efflux transporter confers tolerance to phytoalexins and, thus, clearly is involved in virulence of E. amylovora on apple.

\section{MATERIALS AND METHODS}

\section{Bacterial strains, plasmids, and growth conditions.}

Bacterial strains and plasmids used in this study are listed in Tables 4, 5, and 6. E. amylovora strains and strains of related plant-associated bacteria were cultured at $28^{\circ} \mathrm{C}$ on Luria-Bertani (LB) medium or asparagine minimal medium 2 (AMM2). The AMM2 has the following composition (per liter of demineralized water): fructose, $10 \mathrm{~g}$; L-asparagine, $4 \mathrm{~g} ; \mathrm{Na}_{2} \mathrm{HPO}_{4} \times 7 \mathrm{H}_{2} \mathrm{O}$, $12.8 \mathrm{~g} ; \mathrm{K}_{2} \mathrm{HPO}_{4}, 3 \mathrm{~g} ; \mathrm{NaCl}, 3 \mathrm{~g} ; \mathrm{MgSO}_{4} \times 7 \mathrm{H}_{2} \mathrm{O}, 0.2 \mathrm{~g}$; nicotinic acid, $0.25 \mathrm{~g}$; and thiamine, $200 \mu \mathrm{g}$. Where indicated, antibiotics were added to the media. Escherichia coli strains DH5 $\alpha$ and KAM3 (Morita et al. 1998) were used as cloning hosts. KAM3, a derivative of Escherichia coli TG1 with a deletion in the chromosomal $a c r A B$ genes, also was used for drug susceptibility testing. Escherichia coli cells were maintained routinely at $37^{\circ} \mathrm{C}$ in LB medium, supplemented with ampicillin (Ap) at $50 \mu \mathrm{g} / \mathrm{ml}$, chloramphenicol $(\mathrm{Cm})$ at $25 \mu \mathrm{g} / \mathrm{ml}$, and $\mathrm{Km}$ at $25 \mu \mathrm{g} / \mathrm{ml}$ when necessary. Bacterial growth was monitored with a spectrophotometer (optical density at $600 \mathrm{~nm}\left[\mathrm{OD}_{600}\right]$ ).

\section{Standard genetic procedures.}

Restriction digestions, agarose gel electrophoresis, purification of DNA fragments from agarose gels, electroporation, PCR, and small-scale plasmid DNA preparation were performed by standard techniques (Sambrook and Russel 2001). Cloning was done in pBBR1MCS (Kovach et al. 1995). Largescale preparation of plasmid DNA from Escherichia coli was performed by alkaline lysis and purification with Qiagen tip 100 columns (Qiagen, Hilden, Germany). Southern blot hybridizations were carried out according to the DIG DNA labeling kit (Roche Diagnostics, Mannheim, Germany) following the manufacturer's recommendation. Oligonucleotide primers specific for the PCR-amplification of acrB in Escherichia coli are 5'-CACGCTAACAATGTTCGG (acrB_Ec_fwd) and 5'-G CACCAGTACTGATAACC (acrB_Ec_rev), and for the ampli-

Table 6. Plasmids used in this study

\begin{tabular}{|c|c|c|}
\hline Plasmid & Relevant characteristics & Reference or source \\
\hline pBluescript II SK(+) & $\mathrm{Ap}^{\mathrm{r}}, \mathrm{ColE} 1$ origin & Stratagene \\
\hline pBBR1MCS & $\mathrm{Cm}^{\mathrm{r}}, \mathrm{ColE} 1$ origin & Kovach et al. 1994 \\
\hline pCAM140 & $\mathrm{Sm}^{\mathrm{r}} \mathrm{Sp}^{\mathrm{r}} \mathrm{Ap}^{\mathrm{r}}, \mathrm{R} 6 \mathrm{~K}$ origin, $\mathrm{mTn} 5 \mathrm{SS} g u s A 40$ & Wilson et al. 1995 \\
\hline pCAM140-MCS & $\begin{array}{l}\text { Ap }^{\mathrm{r}} \text {, R6K origin, pCAM140-derivative without mini-Tn5, contains the multi cloning site of } \\
\text { pBluescript II SK(+) }\end{array}$ & This study \\
\hline pMKm & $\mathrm{Km}^{\mathrm{r}}$, contains a $1.7-\mathrm{kb} \mathrm{Km}^{\mathrm{r}}$ cassette & Murillo et al. 1994 \\
\hline pBBR.acr2 & $\begin{array}{l}\mathrm{Cm}^{\mathrm{r}} \text {, contains a } 8.2-\mathrm{kb} \text { SacI fragment carrying acrRAB of Erwinia amylovora cloned in } \\
\text { pBBR1MCS }\end{array}$ & This study \\
\hline pBBR.acrB & $\mathrm{Cm}^{\mathrm{r}}$, contains a 3.1-kb SacI/BamHI fragment derived from pBBR.acr2 in pBBR1MCS & This study \\
\hline pBBR.acrB-Km & $\mathrm{Cm}^{\mathrm{r}} \mathrm{Km}^{\mathrm{r}}$, insertion of $\mathrm{Km}^{\mathrm{r}}$ cassette in $S a c$ II-sites of $a c r B$ gene in pBBR.acrB & This study \\
\hline pCAM.acr-Km & $\mathrm{Ap}^{\mathrm{r}} \mathrm{Km}^{\mathrm{r}}$, contains a 3.8-kb SacI-BamHI fragment derived from pBBR.acrB-Km in pCAM140-MCS & This study \\
\hline pJBA24 & $\mathrm{Ap}^{\mathrm{r}}, \mathrm{pUC} 18 \mathrm{Not}-\mathrm{P}_{\mathrm{A} 1 / 04 / 03}-\mathrm{RBSII}-\mathrm{T}_{0}-\mathrm{T}_{1}$ & Andersen et al. 1998 \\
\hline pEGFP & $\mathrm{Ap}^{\mathrm{r}}$, donor of $e g f p$ gene & BD Biosciences Clontech \\
\hline pJBA24.egfp & $\mathrm{Ap}^{\mathrm{r}}, \mathrm{pUC} 18 \mathrm{Not}-\mathrm{P}_{\mathrm{A} 1 / 04 / 03}-\mathrm{RBSII}-e g f p-\mathrm{T}_{0}-\mathrm{T}_{1}$ & H. Weingart \\
\hline pBBR.egfp.TIR & $\mathrm{Cm}^{\mathrm{r}}$, contains the TIR-egfp- $\mathrm{T}_{0}$ cassette in the opposite orientation to $\mathrm{P}_{\mathrm{lac}}$ in $\mathrm{pBBR} 1 \mathrm{MCS}$ & H. Weingart \\
\hline pBBR.egfp.acrA & $\begin{array}{l}\mathrm{Cm}^{\mathrm{r}} \text {, contains a 1-kb BamHI fragment derived from pBBR.acr2 carrying the promoter region of } \\
\text { acrAB/acrR, transcriptional fusion of } a c r A B \text { with } e g f p\end{array}$ & This study \\
\hline pBBR.egfp.acrR & $\begin{array}{l}\text { As pBBR.egfp.acrA, but with the 1-kb BamHI fragment in the opposite orientation, transcriptional } \\
\text { fusion of } a c r R \text { with } e g f p\end{array}$ & This study \\
\hline
\end{tabular}


fication of $a c r B$ in E. amylovora are 5'-GCCGATTGAGCA ATATCC (acrB_Ea_fwd) and 5'-CACAGGATGGCTGTGTTC (acrB_Ea_rev).

\section{Cloning and sequencing of the $\operatorname{acr} A B$ region of E. amylovora.}

Cloning of the $a c r A B$ region of E. amylovora Ea1189 was performed by functional complementation of the hypersensitive Escherichia coli strain KAM3 as detailed below. Genomic DNA was isolated from Ea1189 based on the method by Wilson (1994) and subsequently digested with the restriction enzyme SacI. According to a shotgun cloning approach, DNA fragments of various sizes were ligated into the vector pBBR1MCS. Competent KAM3 cells were transformed with the ligation products and spread on LB agar plates supplemented with $\mathrm{Cm}$ and crystal violet $(5 \mu \mathrm{g} / \mathrm{ml})$. The latter was used for selection of the $a c r A B$ region according to the results of Nishino and Yamaguchi (2001), who indicated crystal violet as substrate of the AcrAB efflux pump in Escherichia coli. This led to the isolation of pBBR.acr2 carrying putative drug transporter ORFs for crystal violet resistance. To determine the nucleotide sequence of the complete 8.5$\mathrm{kb}$ DNA insert of pBBR.acr2 the template generation system (TGS) (Finnzymes, Espoo, Finland) was used according to the manufacturer's instructions. The subsequent nucleotide sequencing using appropriate subclones was performed commercially (MWG Biotech, Ebersberg, Germany). Nucleotide sequence data were aligned and processed with Lasergene sequence analysis software (version 5.0; DNASTAR Inc., Madison, WI) and Vector NTI (suite 8; InforMax Inc., North Bethesda, MD). DNA and protein sequence similarity searches in databases were performed with programs based on the BLAST algorithm (Altschul et al. 1997) provided by the Bioinformatics Center of the Institute for Chemical Research, Kyoto University. The PROSITE database on the ExPASy Molecular Biology server of the Swiss Institute of Bioinformatics, Geneva was used for scanning protein sequences for motifs. Prediction of topology and localization of $\alpha$ helices in transmembrane proteins was achieved with the program HMMTOP2.0 (Institute of Enzymology at the Biological Research Center of the Hungarian Academy of Sciences, Budapest). The prediction of signal peptide sequences was performed with the SignalP program (version 2.0; Center for Biological Sequence Analysis, Technical University of Denmark, Lyngby).

\section{Generation of acrB-deficient mutants of E. amylovora by marker exchange mutagenesis.}

pCAM-MCS, a suicide vector for members of Enterobacteriaceae, was used for generation of a gene disruption mutant in E. amylovora Ea1189. This vector was created by deleting miniTn 5 and transposase of pCAM140 (Wilson et al. 1995) by SalI/EcoRI-digest and insertion of a $S a c \mathrm{I} / K p n I$ fragment containing the multicloning site of pBluescript II $\mathrm{SK}(+)$ (Stratagene, Heidelberg, Germany) by blunt-end ligation. Escherichia coli S17-1 $\lambda$-pir was used as delivery host for pCAM-MCS derivatives.

An acrB-deficient mutant of E. amylovora was generated by marker exchange mutagenesis as follows. A $4.4-\mathrm{kb}$ BamHI/SacI fragment containing $a c r B$ was subcloned from pBBR.acr2 into pBBR1MCS to create pBBR.acrB. The $a c r B$ gene was disrupted by insertion of an $1.7-\mathrm{kb} \mathrm{Km}$-resistance cassette that was derived from plasmid pMKm (Murillo et al. 1994) into SacII-restriction sites. The resulting plasmid pBBR.acrB-Km was digested with BamHI/SacI and the 5.1-kb fragment was subcloned by blunt-end ligation into the unique EcoRV restriction site of pCAM-MCS to generate pCAM.acrB-Km. This plasmid was transformed into electrocompetent $E$. amylovora cells, which subsequently were grown at $28^{\circ} \mathrm{C}$ for $1 \mathrm{~h}$ in SOC broth (Sambrook and Russel 2001) and plated on AMM2 containing $\mathrm{Km}(400 \mu \mathrm{g} / \mathrm{ml})$. To exclude mutants that resulted from single crossover events, colonies then were transferred parallel onto LB agar plates supplemented with $\mathrm{Km}(100 \mu \mathrm{g} / \mathrm{ml})$ and onto AMM2 agar plates supplemented with Ap $(800 \mu \mathrm{g} / \mathrm{ml})$. Several Km-resistant and Ap-sensitive colonies were selected and their genotypes were verified by PCR and Southern blot analyses.

\section{Plant materials, pathogenicity assay on apple, and HR assay on tobacco.}

Apple plants (rootstock Malus MM106) and tobacco plants (Nicotiana tabacum cv. Petit Havana SR1) were grown in a greenhouse at 20 to $25^{\circ} \mathrm{C}, 60 \%$ humidity, with a 12-h photoperiod (15,000 lux). E. amylovora mutant Ea1189-3 and the parent strain Ea1189, grown on LB agar plates for $48 \mathrm{~h}$, were resuspended and diluted to a cell density of $1 \times 10^{6} \mathrm{CFU} / \mathrm{ml}$ in sterile demineralized water for inoculation. Apple plants were inoculated by the prick technique as described by May and associates (1997). Each bacterial strain was inoculated into one shoot of five single plants. Bacterial suspension $(5 \mu \mathrm{l})$ was placed onto each wound on the shoot tip. Plants were monitored for symptom development daily. The experiment was repeated three times. Survival of bacteria in the plant tissue was examined by re-isolation of bacterial cells 1 day after inoculation of 15 plants. Again, $5 \mu \mathrm{l}$ of bacterial suspension $\left(10^{2}\right.$ to $\left.10^{6} \mathrm{CFU} / \mathrm{ml}\right)$ was placed onto each wound on the shoot tip. After $24 \mathrm{~h}, 1 \mathrm{~cm}$ of the shoot tip around the inoculation area was cut off. Samples were pooled, homogenized in isotonic $\mathrm{NaCl}$, and serially diluted, and appropriate dilutions were spread on LB agar plates.

Tobacco plants were inoculated with bacterial suspensions $\left(10^{9} \mathrm{CFU} / \mathrm{ml}\right)$ by injection of leaf veins of the third and fourth leaf with a syringe. Sterile demineralized water was used as a negative control. Infiltrated areas were monitored for development of HR in the form of necrosis after 24 and $48 \mathrm{~h}$. All greenhouse experiments were repeated at least three times to confirm reproducibility and to calculate standard deviations.

\section{Extraction of lipophilic secondary metabolites from plant tissue.}

Secondary metabolites of apple rootstock MM106 were extracted from leaf tissue which was homogenized initially in liquid nitrogen in a mortar. Homogenate $(1 \mathrm{~g})$ was extracted with $1 \mathrm{ml}$ of methanol and subsequently centrifuged to separate liquid and pellet. Biological activity of the crude methanol extracts was examined by agar diffusion assays.

\section{Agar plate diffusion assay.}

E. amylovora Ea1189 and the acrB mutant Ea1189-3 were used as test organisms to evaluate the antimicrobial activity of crude plant extracts. Bacteria strains were incubated for $20 \mathrm{~h}$ in AMM2 and diluted to $10^{9} \mathrm{CFU} / \mathrm{ml}$ in isotonic $\mathrm{NaCl}$. For preparation of the test plates (150 $\mathrm{mm}$ in diameter), $50 \mathrm{ml}$ of AMM2 agar was warmed to $48^{\circ} \mathrm{C}$ and supplemented with $500 \mu \mathrm{l}$ of the diluted cell suspension. Holes $10 \mathrm{~mm}$ in diameter were punched into each plate by a cork borer and $50 \mu \mathrm{l}$ of test solution was poured into each hole. On each plate, $50 \mu \mathrm{l}$ of spectinomycin $(5 \mathrm{mg} / \mathrm{ml})$ was used as control. After $24 \mathrm{~h}$ of incubation at $28^{\circ} \mathrm{C}$, the test plates were monitored for zones of growth inhibition on the bacterial lawn.

\section{Drug susceptibility tests.}

The MICs of drugs on Escherichia coli and E. amylovora strains were determined by a broth microdilution assay in Mueller-Hinton broth (MHB) (Becton Dickinson, Heidelberg, Germany) and AMM2, respectively. All tests were done in triplicate following the National Committee for Clinical Laboratory Standards (2000) recommendations. Briefly, testing of 
MIC was carried out in microtiter plates with 96 flat-bottomed wells. With the exception of those wells used as controls, each well received $100 \mu$ l of a twofold dilution series of an antibiotic solution in the appropriate medium. Then, each well, except those used as sterility controls, received $100 \mu \mathrm{l}$ of bacterial suspension (Escherichia coli: $\mathrm{MHB}$ at $10^{6} \mathrm{CFU} / \mathrm{ml} ; E$. amylovora: AMM2 at $\left.2 \times 10^{6} \mathrm{CFU} / \mathrm{ml}\right)$. The MIC is defined as the lowest concentration of an antibiotic that completely stops visible cell growth. Growth of Escherichia coli at $37^{\circ} \mathrm{C}$ and of E. amylovora at $28^{\circ} \mathrm{C}$ was examined by visual inspection after $24 \mathrm{~h}$ of incubation.

\section{Promoter activity of $a c r A B$ and $a c r R$ in vitro.}

The reporter gene egfp was employed to study the promoter activities of $a c r A B$ and $a c r R$. Transcriptional fusions between the promoter regions and egfp were created in vector pBBR.egfp.TIR. This vector carries the egfp flanked by an optimized translational initiation region, translational stop codons, and a transcriptional terminator.

Construction of pBBR.egfp.TIR was done as follows. PCR amplification with primer egfp-Sph (5'-ATATAGCATGC TGAGCAAGGGCGAGGAGCTGT-3') and primer egfp-Hind (5'-CTCTCAAGCTTACTTGTACAGCTCGTCCATGC-3') and with plasmid pEGFP (BD Biosciences Clontech, Heidelberg, Germany) as the template resulted in a $0.72-\mathrm{kb}$ fragment. This fragment subsequently was inserted into SphI-HindIII-digested pJBA24 (Andersen et al. 1998). The resulting plasmid, pJBA24.egfp, was used as a template in a PCR with the primer set egfp-TIR (5'-ATCGGTACCTGATTAACTTTATAAGGAG GAAAAACGCATGCTGAGCAAGGGCGAGGAGC-3') and egfp-T0 (5'-GGAGGTACCAACGGTGGTATATCCAGT-3') to amplify a $0.94-\mathrm{kb}$ fragment containing a translational initiation region with an optimized Shine-Dalgarno sequence and the translational enhancer of gene 10 of phage T7 (Miller and Lindow 1997), followed by the egfp gene, translational stop codons in all three reading frames, and the strong transcriptional terminator $\mathrm{T}_{0}$ from phage $\lambda$ (Andersen et al. 1998). The PCR product was digested with KpnI and cloned into KpnI-digested pBBR1MCS to create vector pBBR.egfp.TIR.

In pBBR.egfp.TIR, egfp is orientated in the opposite direction to the promoter of lac $Z^{\prime}$. From plasmid pBBR.acr2, a 1$\mathrm{kb} B a m \mathrm{HI}$ fragment containing the promoter region of $a c r A B$ and $a c r R$, respectively, was obtained and inserted into the BamHI site of pBBR.egfp.TIR. The orientation of the insert was determined by restriction with HincII and SpeI. The resulting plasmids, pBBR.egfp.acrA and pBBR.egfp.acrR, were transformed into E. amylovora Ea1189. The impact of substrates of the transport system AcrAB on transcriptional activity of either $a c r A B$ or $a c r R$ was detected in microtiter plates. According to the microdilution assay, different substrate concentrations were tested by serial twofold dilutions in AMM2 and bacterial cells at $10^{8} \mathrm{CFU} / \mathrm{ml}$ used as inocula. Fluorescence of EGFP was measured directly in the microtiter plates after $24 \mathrm{~h}$ of incubation at $28^{\circ} \mathrm{C}$. The fluorescence was calculated for bacterial suspensions with an $\mathrm{OD}_{600}=0.1$.

To assay fluorescence during growth in liquid cultures, aliquots of the cultures were harvested at distinct optical densities, centrifuged, resuspended in phosphate-buffered saline, and adjusted to an $\mathrm{OD}_{600}$ value of 0.5 . Fluorescence was quantified using a Fluorolite-100 microplate reader set to an excitation wavelength of $470 \mathrm{~nm}$ with emission detection at $516 \mathrm{~nm}$.

\section{Promoter activity of $a c r A B$ and $a c r R$ in planta.}

To study in planta activity of the promoters of $a c r A B$ and acrR, E. amylovora Ea1189 harboring pBBR.egfp.acrA and
pBBR.egfp.acrR, respectively, was inoculated at $10^{6} \mathrm{CFU} / \mathrm{ml}$ in apple rootstock MM106. Inoculation was carried out as described above. To assay fluorescence of bacterial cells, infected plant tissue was macerated in isotonic $\mathrm{NaCl}$ and imaged by confocal laser scanning microscopy. Bacteria were re-isolated 1,3 , and 4 days after inoculation. The fluorescence of reisolated bacteria and bacteria from the stationary growth phase in a liquid culture were compared. The fluorescence of 25 cells per sample was quantified and the average calculated.

\section{ACKNOWLEDGMENTS}

This study was supported by grants from the Max Planck Society, Germany. We thank T. Tsuchiya and Y. Morita of Okayama University, Japan for providing the Escherichia coli strain KAM3; and I. Barash, F. Boernke, A. Collmer, D. L. Coplin, K. Geider, K. Rudolph, and B. Völksch for providing strains of E. amylovora and of related plant-associated bacteria.

\section{LITERATURE CITED}

Aldridge, P., Metzger, M., and Geider, K. 1997. Genetics of sorbitol metabolism in Erwinia amylovora and its influence on bacterial virulence. Mol. Gen. Genet. 256:611-619.

Altschul, S. F., Madden, T. L., Schaffer, A. A., Zhang, J., Zhang, Z., Miller, W., and Lipman, D. J. 1997. Gapped BLAST and PSI-BLAST: a new generation of protein database search programs. Nucleic Acids Res. 25:3389-3402.

Andersen, J. B., Sternberg, C., Poulsen, L. K., Bjorn, S. P., Givskov, M., and Molin, S. 1998. New unstable variants of green fluorescent protein for studies of transient gene expression in bacteria. Appl. Environ. Microbiol. 64:2240-2246.

Aramaki, H., Yagi, N., and Suzuki, M. 1995. Residues important for the function of a multihelical DNA binding domain in the new transcription factor family of Cam and Tet repressors. Protein Eng. 8:1259-66.

Barny, M. A., Guinebretière, M. H., Marçais, B., Coissac, E., Paulin, J.P., and Laurent, J. 1990. Cloning of a large gene cluster involved in Erwinia amylovora CFBP 1430 virulence. Mol. Microbiol. 4:777-786.

Bellemann, P., and Geider, K. 1992. Localization of transposon insertions in pathogenicity mutants of Erwinia amylovora and their biochemical characterization. J. Gen. Microbiol. 138:931-940.

Blackmore, C. G., McNaughton, P. A., and van Veen, H. W. 2001. Multidrug transporters in prokaryotic and eukaryotic cells: physiological functions and transport mechanisms. Mol. Membr. Biol. 18:97-103.

Bogs, J., and Geider, K. 2000. Molecular analysis of sucrose metabolism of Erwinia amylovora and influence on bacterial virulence. J. Bacteriol. 182:5351-5358.

Brown, M. H., Paulsen I. T., and Skurray R. A. 1999. The multi-drug efflux protein NorM is a prototype of a new family of transporters. Mol. Microbiol. 31:394-395

Del Sorbo, G., Schoonbeek, H.-J., and De Waard, M. A. 2000. Fungal transporters involved in efflux of natural toxic compounds and fungicides. Fungal Genet. Biol. 30:1-15.

Dinh, T., Paulsen, I. T., and Saier, M. H., Jr. 1994. A family of extracytoplasmic proteins that allow transport of large molecules across the outer membranes of gram-negative bacteria. J. Bacteriol. 176:3825-3831.

Eastgate, J. A. 2000. Erwinia amylovora: the molecular basis of fire blight disease. Mol. Plant Pathol. 1:325-329.

Expert, D., Dellagi, A., and Kachadourian, R. 2000. Iron and fire blight: role in pathogenicity of desferroxamine E, the main siderophore of Erwinia amylovora. Pages 179-195 in: Fire Blight: The Disease and Its Causative Agent, Erwinia amylovora. J. L. Vanneste, ed. CABI Publishing, Oxon, U.K.

Fleißner, A., Sopalla, C., and Weltring, K.-M. 2002. An ATP-binding cassette multi-drug-resistance transporter is necessary for tolerance of Gibberella pulicaris to phytoalexins and virulence on potato tubers. Mol. Plant-Microbe Interact. 15:102-108.

Fralick, J. A. 1996. Evidence that TolC is required for functioning of the Mar/AcrAB efflux pump of Escherichia coli. J. Bacteriol. 178:58035805.

Gonzales-Pasayo, R., and Martinez-Romera, E. 2000. Multiresistance genes of Rhizobium etli CFN42. Mol. Plant-Microbe Interact. 13:572-577.

Grayer, R. J., and Kokubun, T. 2001. Plant-fungal interactions: the search for phytoalexins and other antifungal compounds from higher plants. Phytochemistry 56:253-263.

Grkovic, S., Brown, M. H., and Skurray, R. A. 2002. Regulation of bacterial export systems. Microbiol. Mol. Biol. Rev. 66:671-701. 
Hagmann , K. E., Pan, W., Spratt, B. G., Balthazar, J. T., Judd, R. C., and Schafer, W. M. 1995. Resistance of Neisseria gonorrhoeae to antimicrobial hydrophobic agents is modulated by the mtrRCDE efflux system. Microbiology 141:611-622.

Harborne, J. B. 1999. The comparative biochemistry of phytoalexin induction in plants. Biochem. System. Ecol. 27:335-367.

Hauben, L., Moore, E. R. B., Vauterin, L., Steenackers, M., Mergaert, J., Verdonck, L., and Swings, J. 1998. Phylogenetic position of phytopathogens within the Enterobacteriaceae. Syst. Appl. Microbiol. 21:384397.

Koehler, T., Michea-Hamzehpour, M., Henze, U., Gotoh, N., Curty, L. K., and Pechere, J. C. 1997. Characterization of MexE-MexF-OprN, a positively regulated multi-drug efflux system of Pseudomonas aeruginosa. Mol. Microbiol. 23:345-354.

Kovach, M. E., Elzer, P. H., Hill, D. S., Robertson, G. T., Farris, M. A., Roop, R. M., II, and Peterson, K. M. 1995. Four new derivatives of the broad-host-range cloning vector pBBR1MCS, carrying different antibiotic-resistance cassettes. Gene 166:175-176.

Krummenacher, P., and Narberhaus, F. 2000. Two genes encoding a putative multi-drug efflux pump of the RND/MFP family are cotranscribed with an rpoH gene in Bradyrhizobium japonicum. Gene 241:247-254.

Lam, E., Kato, N., and Lawton, M. 2001. Programmed cell death, mitochondria and the plant hypersensitive response. Nature 411:848-853.

Li, X.-Z., Nikaido, H., and Poole, K. 1995. Role of MexA-MexB-OprM in antibiotic efflux in Pseudomonas aeruginosa. Antimicrob. Agents Chemother. 39:1948-1953.

Lomovskaya, O., Zgurskaya, H. I., and Nikaido, H. 2002. It takes three to tango. Nat. Biotechnol. 20:1210-1212.

Ma, D., Alberti, M., Lynch, C., Nikaido, H., and Hearst, J. E. 1996. The local repressor AcrR plays a modulating role in the regulation of acrAB genes of Escherichia coli by global stress signals. Mol. Microbiol. 19:101-112.

Ma, D., Cook, D. N., Alberti, M., Pon, N. G., Nikaido, H., and Hearst, J E. 1993. Molecular cloning and characterization of acrA and acrE genes of Escherichia coli. J. Bacteriol. 175:6299-313.

Ma, D., Cook, D. N., Alberti, M., Pon, N. G., Nikaido, H., and Hearst, J. E. 1995. Genes $a c r A$ and $a c r B$ encode a stress-induced efflux system in Escherichia coli. Mol. Microbiol. 16:45-55.

May, R., Völksch, B., and Kampmann, G. 1997. Antagonistic activities of epiphytic bacteria from soybean leaves against Pseudomonas syringae pv. glycinea in vitro and in planta. Microb. Ecol. 34:118-124.

Mayr, U., Treutter, D., Santos-Buelga, C., Bauer, H., and Feucht, W. 1995. Developmental changes in the phenol concentrations of 'Golden Delicious' apple fruits and leaves. Phytochemistry 38:1151-1155.

Metzger, M., Bellemann, P., Bugert, P., and Geider, K. 1994. Genetics of galactose metabolism of Erwinia amylovora and its influence on polysaccharide synthesis and virulence of the fire blight pathogen. J. Bacteriol. 176:450-459.

Miller, W. G., and Lindow, S. E. 1997. An improved GFP cloning cassette designed for prokaryotic transcriptional fusions. Gene 191:149-153.

Morita, Y., Kodama, K., Shiota, S., Mine, T., Kataoka, A., Mizushima, T. and Tsuchiya, T. 1998. NorM, a putative multi-drug efflux protein, of Vibrio parahaemolyticus and its homolog in Escherichia coli. Antimicrob. Agents Chemother. 42:1778-1782.

Murakami, S., Nakashima, R., Yamashita, E., and Yamaguchi, A. 2002. Crystal structure of bacterial multi-drug efflux transporter AcrB. Nature 419:587-593.

Murillo, J., Shen, H., Gerhold, D., Sharma, A., Cooksey, D. A., and Keen, N. T. 1994. Characterization of pPT23B, the plasmid involved in syringolide production by Pseudomonas syringae pv. tomato PT23. Plasmid 31:275-287.

National Committee for Clinical Laboratory Standards (NCCLS). 2000 Methods for dilution antimicrobial susceptibility tests for bacteria that grow aerobically. Approved Standard, Fifth Edition. NCCLS document M07-A5, Wayne, PA

Nishino, K., and Yamaguchi, A. 2001. Analysis of a complete library of putative drug transporter genes in Escherichia coli. J. Bacteriol. 183:5803-5812.

Okusu, H., Ma, D., and Nikaido, H. 1996. AcrAB efflux pump plays a major role in the antibiotic resistance phenotype of Escherichia coli multipleantibiotic-resistance (mar) mutants. J. Bacteriol. 178:306-308.

Osbourn, A. E. 1996. Preformed antimicrobial compounds and plant defense against fungal attack. Plant Cell 8:1821-1831.

Palumbo, J. D., Kado, C. I., and Phillips, D. A. 1998. An isoflavonoid-inducible efflux pump in Agrobacterium tumefaciens is involved in competitive colonization of roots. J. Bacteriol. 180:3107-3113.

Pao, S. S., Paulsen, I. T., and Saier, M. H., Jr. 1998. Major facilitator superfamily. Microbiol. Mol. Biol. Rev. 62:1-34.

Paulsen, I. T., Brown, M. H., and Scurray, R. A. 1996. Proton-dependent multi-drug efflux systems. Microbiol. Rev. 60:575-608.

Paulsen, I. T., Cen, J., Nelson, K. E., and Saier, M. H., Jr. 2001. Comparative genomics of microbial drug efflux systems. J. Mol. Microbiol. Biotechnol. 3:145-150.

Paulsen, I. T., Park, J. H., Choi, P. S., and Saier, M. H. Jr. 1997. A family of Gram-negative bacterial outer membrane factors that function in export of proteins, carbohydrates, drugs and heavy metals from Gramnegative bacteria. FEMS (Fed. Eur. Microbiol. Soc.) Microbiol. Lett. 156:1-8.

Peng, W.-T., and Nester, E. W. 2001. Characterization of a putative RNDtype efflux system in Agrobacterium tumefaciens. Gene 270:245-252.

Poole, K. 2000. Efflux-mediated resistance to fluoroquinolones in gramnegative bacteria. Antimicrob. Agents Chemother. 44:2233-2241.

Poole, K., Krebes, K., McNally, C., and Neshat, S. 1993. Multiple antibiotic resistance in Pseudomonas aeruginosa: evidence for involvement of an efflux operon. J. Bacteriol. 175:7363-7372.

Pradel, E., and Pagès, J.-M. 2002. The AcrAB-TolC efflux pump contributes to multidrug resistance in the nosocomial pathogen Enterobacter aerognes. Antimicrob. Agents Chemother. 46:2640-2643.

Psallidas, P. G., and Tsiantos, J. 2000. Chemical control of fire blight. Pages 199-234 in: Fire Blight: The Disease and Its Causative Agent, Erwinia amylovora. J. L. Vanneste, ed. CABI Publishing, Oxon, UK.

Ramos, J. L., Duque, E., Godoy, P., and Segura, A. 1998. Efflux pumps involved in toluene tolerance in Pseudomonas putida DOT-T1E. J. Bacteriol. 80:3323-3329.

Saier, M. H., Jr., Beatty, J. T., Goffeau, A., Harley, K. T., Heijne, W. H., Huang, S. C., Jack, D. L., Jahn, P. S., Lew, K., Liu, J., Pao, S. S. Paulsen, I. T., Tseng, T. T., and Virk, P. S. 1999. The major facilitator superfamily. J. Mol. Microbiol. Biotechnol. 1:257-279.

Sambrook, J., and Russel, D. W. 2001. Molecular Cloning: A Laboratory Manual. Cold Spring Harbor Laboratory Press, Cold Spring Harbor, NY.

Schoonbeek, H., Del Sorbo, G., and De Waard, M. A. 2001. The ABC transporter BcatrB affects the sensitivity of Botrytis cinerea to the phytoalexin resveratrol and the fungicide fenpiclonil. Mol. Plant-Microbe Interact. 14:562-571

Steinberger, E. M., and Beer, S. V. 1988. Creation and complementation of pathogenicity mutants of Erwinia amylovora. Mol. Plant-Microbe Interact. 1:135-144.

Sulavik, M. C., Houseweart, C., Cramer, C., Jiwani, N., Murgolo, N., Greene, J., DiDomenico, B., Shaw, K. J., Miller, G. H., Hare, R., and Shimer, G. 2001. Antibiotic susceptibility profiles of Escherichia coli strains lacking multi-drug efflux pump genes. Antimicrob. Agents Chemother. 45:1126-1136.

Treutter, D. 2001. Biosynthesis of phenolic compounds and its regulation in apple. Plant Grow. Regul. 34:71-89.

Tseng, T. T., Gratwick, K. S., Kollman, J., Park, D., Nies, D. H., Goffeau, A., and Saier, M. H., Jr. 1999. The RND permease superfamily: an ancient, ubiquitous and diverse family that includes human disease and development proteins. J. Mol. Microbiol. Biotechnol. 1:107-125.

Urban, M., Bhargava, T., and Hamer, J. E. 1999. An ATP-driven efflux pump is a novel pathogenicity factor in rice blast disease. EMBO J. 18:512-521.

van Bambeke, F., Balzi, E., and Tulkens, P. M. 2000. Antibiotic efflux pumps. Biochem. Pharmacol. 60:457-470.

VanEtten, H., Temporine, E., and Wasmann, C. 2001. Phytoalexin (and Phytoanticipin) tolerance as a virulence trait: why is it not required by all pathogens? Physiol. Mol. Plant Pathol. 59:83-93.

van Gijsegem, F. 1997. In planta regulation of phytopathogenic bacteria virulence genes: relevance of plant-derived signals. Eur. J. Plant Pathol. 103:291-301

Vanneste, J. L. and Eden-Green, S. 2000. Migration of Erwinia amylovora in host plant tissue. Pages 9-36 in: Fire Blight: The Disease and Its Causative Agent, Erwinia amylovora. J. L. Vanneste, ed. CABI Publishing, Oxon, UK

Vanneste, J. L., Paulin, J.-P., and Expert, D. 1990. Bacteriophage Mu as a genetic tool to study Erwinia amylovora pathogenicity and hypersensitive reaction on tobacco. J. Bacteriol. 172:932-941.

Walsh, C. 2000. Molecular mechanisms that confer antibacterial drug resistance. Nature 406:775-781.

Wilson, K. 1994. Preparation of genomic DNA from bacteria. Pages 2.4.1.-2.4.5. in: Current Protocols in Molecular Biology. F. M. Ausubel, R. Brent, R. E. Kingston, D. D. Moore, J. G. Seidmann, J. A Smith, and K. Struhl, eds. John Wiley \& Sons, NY.

Wilson, K. J., Sessitsch, A., Corbo, J. C., Giller, K. E., Akkermans, A. D. L., and Jefferson, R. A. 1995. Glucuronidase (GUS) transposons for ecological and genetic studies of rhizobia and other Gram-negative bacteria. Microbiology 141:1691-1705.

Zgurskaya, H. I., and Nikaido, H. 2000. Multi-drug resistance mechanisms: drug efflux across two membranes. Mol. Microbiol. 37:219-225. 